\title{
Pleistocene sediment offloading and the global sulfur cycle
}

\author{
S. Markovic ${ }^{1}$, A. Paytan ${ }^{2}$, and U. G. Wortmann ${ }^{1}$ \\ ${ }^{1}$ Department of Geology, University of Toronto, 22 Russell St. M5S3B1, Toronto, Canada \\ ${ }^{2}$ Institute of Marine Sciences, University of California Santa Cruz, Santa Cruz, CA 94064, USA
}

Correspondence to: S. Markovic (stefa.markovic@utoronto.ca)

Received: 4 December 2014 - Published in Biogeosciences Discuss.: 16 January 2015

Revised: 31 March 2015 - Accepted: 24 April 2015 - Published: 27 May 2015

\begin{abstract}
Quaternary sea level fluctuations have greatly affected the sediment budgets of the continental shelves. Previous studies suggested that this caused a considerable increase in the net loss of shelf sediments. Since sediment accumulation and erosion are closely tied to the formation and re-oxidation of pyrite, we use a high-resolution record of sulfur isotope ratios $\left({ }^{34} \mathrm{~S} /{ }^{32} \mathrm{~S}\right)$ of marine sulfate to evaluate the implications of the so-called "shelf sediment offloading" on the global sulfur cycle. Modeling of our $\delta^{34} \mathrm{~S}$ record suggests that erosion during sea level lowstands was only partly compensated by increased sedimentation during times of rising sea level and sea level highstands. Furthermore, our data suggests that shelf systems reached a new equilibrium state about $700 \mathrm{ka}$, which considerably slowed or terminated shelf sediment offloading.
\end{abstract}

\section{Introduction}

The Pliocene-early Pleistocene was characterized by relatively small $(20-50 \mathrm{~m})$ but frequent sea level changes in the precession and obliquity frequency bands (Miller et al., 2011). During the Middle Pleistocene, this pattern changed and large sea level fluctuations in the $100 \mathrm{ky}$ frequency range gradually became dominant. At times, global sea level dropped as low as $130-150 \mathrm{~m}$ below present day sea level (Miller et al., 2011), exposing large areas of shelf to weathering and erosion. These sea level changes must have fundamentally altered the balance between sedimentation and erosion on continental shelves. Hay and Southam (1977) proposed that the repeated exposure and inundation of the continental shelves has led to a massive transfer of sediments from continental shelves to the deep ocean. They estimate that as much as $5 \times 10^{21} \mathrm{~g}$ of detrital sediment may have been removed by this so-called "sediment offloading" (Hay and Southam, 1977).

Although intuitively a convincing hypothesis, a quantitative analysis which includes the rates of sediment delivery to the deep ocean is missing. Hay and Southam (1977) hypothesized that the pattern of sea level falls controls the sediment delivery into the deep ocean. For example, during the first large sea level drop sediment transfer would be exceptionally large and the intensity of sediment erosion will decrease with consequent events, as the sediment reservoir available for erosion will become depleted (Hay and Southam, 1977; Hay, 1998; Hay et al., 2002).

Adding/removing sediments from the shelf is closely coupled to the burial/erosion of pyrite in those sediments. During interglacials, high sea levels result in expanded shelf areas. Coincidentally, the shelf areas are characterized by high pyrite burial rates (Jørgensen, 1982; Berner, 1982). During sea level lowstands, formerly inundated shelf areas are being replaced by low-lying coastal plains transected by rivers. This affects sedimentary sulfur cycling in two ways: (1) pyrite burial is reduced, and (2) fine-grained and unlithified sediments in the exposed shelf (de Haas et al., 2002) are eroded (Gibbs and Kump, 1994; Foster and Vance, 2006) and pyrite and organic sulfur (S) contained in the eroded sediments are oxidized (Turchyn and Schrag, 2004).

Pyrite formation is mediated by microbial sulfate reduction (MSR) and microbial sulfur disproportionation, which produce a large $\mathrm{S}$-isotope ratio difference between pyrite and concomitant seawater sulfate (up to 70\%o; Canfield and Thamdrup, 1994; Wortmann et al., 2001; Rudnicki et al., 2001; Böttcher et al., 2001, 2005; Brunner and Bernasconi, 2005; Sim et al., 2011). Accordingly, the burial of large amounts of pyrite will result in a more positive sulfur isotope value of seawater sulfate $\left(\delta^{34} S\right)$, whereas the oxidation 
of large amounts of pyrite will cause a decrease of the seawater sulfate $\delta^{34} \mathrm{~S}$ value. In the following, we take advantage of this relationship and use past changes of seawater sulfate $\delta^{34} \mathrm{~S}$ value to track changes in pyrite burial/oxidation on continental shelves and their relation to changes in global sea level.

The $\delta^{34} \mathrm{~S}$ value of seawater sulfate is uniform throughout the ocean, reflecting the long residence time of marine sulfate ( 10-20 Myr; Jørgensen and Kasten, 2006) compared to the ocean mixing time $(\sim 1600 \mathrm{yr})$. The evolution of the $\delta^{34} \mathrm{~S}$ value of sulfate thus serves as a proxy for past changes in the sulfur cycle (Paytan et al., 1998, 2004; Wortmann and Chernyavsky, 2007; Wortmann and Paytan, 2012).

Authigenic marine barite crystals continuously record past changes of seawater sulfate $\delta^{34} \mathrm{~S}$ value (Paytan et al., 1998). Here we use a new high-resolution marine barite $\delta^{34} \mathrm{~S}$ record of the last $3 \mathrm{Myr}$ to delineate the onset and duration of these changes, which allows us to validate/test the shelf sediment offloading hypothesis.

\section{Geological setting}

We use sediment samples from eastern equatorial $\mathrm{Pa}$ cific sites 849D $\left(0^{\circ} 10.993^{\prime} \mathrm{N}, 110^{\circ} 31.167^{\prime} \mathrm{W}\right)$ and $851 \mathrm{~B}$ $\left(2^{\circ} 46.223^{\prime} \mathrm{N}, 110^{\circ} 34.308^{\prime} \mathrm{W}\right)$ obtained by advanced piston coring (APC) during Leg 138 of the Ocean Drilling Program (ODP). Site 849D is located below a highly productive equatorial divergence zone at a depth of $3839 \mathrm{~m}$ (Shipboard Scientific party, 1992a). Site 851B is located within the northern limit of western-flowing South Equatorial Current at the depth of $3760 \mathrm{~m}$, within the equatorial high-productivity zone (Shipboard Scientific Party, 1992b).

Sediments at both locations consist of diatom nannofossil ooze (Shipboard Scientific Party, 1992a and b). Sedimentation rates were moderate since the late Pliocene, varying between 25-35 $\mathrm{m} \mathrm{Myr}^{-1}$ at Site 849D and 15-20 $\mathrm{m} \mathrm{Myr}^{-1}$ at Site 851B (Shipboard Scientific Party, 1992a and b).

Marine barite forms in the water column recording seawater $\mathrm{S}$ isotope ratios (Griffith and Paytan, 2012). After burial in the sediment, barite is stable during diagenesis except in environments with high rates of sulfate reduction where sulfate in pore waters is exhausted (e.g., Torres et al., 1996; Griffith and Paytan, 2012). In sulfate-reducing environments, barite is soluble releasing barium to solution. This barium will diffuse and barite will reprecipitate forming diagenetic barite with typically anomalously high $\delta^{34} \mathrm{~S}$ signatures (Paytan et al., 2002). Sites 849D an 851B are characterized by low organic matter $(\mathrm{OM})$ concentrations and high sulfate concentrations in the interstitial waters $(0.2 \mathrm{wt} \%, \mathrm{OM}, 25-28 \mathrm{mM}$ $\mathrm{SO}_{4}^{2-}$; Shipboard Scientific Party, 1992a, b). These conditions suggest that the barite samples in sediments at these sites are not affected by barite dissolution and/or reprecipitation and thus originate from sinking particles in the water column (e.g., marine barite).
Sample ages are estimated using high-resolution (10$50 \mathrm{kyr}$ ) orbitally tuned age models by Shackleton et al. (1995) which are based on magnetostratigraphy, biostratigraphy, gamma ray attenuation porosity measurements (GRAPE) and $\delta^{18} \mathrm{O}$ records of benthic foraminifera.

\section{Methods}

Here, we used the sequential dissolution method of Paytan et al. (1996) to extract barite crystals from marine sediments. We have modified the original method to better address concerns about pyrite contamination (DeBond et al., 2012) and to improve the workflow. Unlike the original method organic matter is removed by heating the sample in the furnace at $700^{\circ} \mathrm{C}$ instead of oxidizing it with hot bleach overnight. We also changed the order of the extraction steps so that iron and manganese oxyhydroxides are now dissolved with $0.2 \mathrm{~N}$ hydroxylamine hydrochloride in $25 \%$ acetic acid at the end of the process. Between steps we centrifuged samples, decanted the supernatant and washed the residue three times with ultrapure deionized water.

In order to prevent oxidation of reduced sulfur during the carbonate leaching process, we added $50 \mathrm{~mL}$ of $5 \%$ tin chloride $\left(\mathrm{SnCl}_{2}\right)$ solution to $1 \mathrm{~L}$ of $\mathrm{HCl}$ to maintain reducing conditions during the leaching step (instead of bubbling $\mathrm{N}_{2}$ gas as in the original procedure). In addition, the $\mathrm{HCl}$ is flushed with Argon before the carbonate dissolution. This is the step in which we expected pyrite to be prone to oxidation if present in the sediments.

We examined the purity of the extracted barite with X-ray diffraction. Furthermore, we checked for presence of diagenetic barite using scanning electron microscopy and Energy dispersive X-ray spectroscopy (Paytan et al., 2002). If samples contained residual mineral phases like rutile, we dissolved the extracted barite with sodium carbonate and subsequently reprecipitated pure $\mathrm{BaSO}_{4}$ (Breit et al., 1985).

\subsection{Isotope analysis}

Sulfur isotopes are analyzed with a continuous flow isotope ratio mass spectrometer system (CFIRMS) using a Eurovector Elemental Analyzer (EA) coupled via a Finnigan Conflo III open split interface to a Finnigan MAT 253 mass spectrometer. Solid barite samples $(200 \mu \mathrm{g})$ are mixed in a tin cup with $\sim 600 \mu \mathrm{g}$ of vanadium pentoxide $\left(\mathrm{V}_{2} \mathrm{O}_{5}\right)$ powder and introduced into the EA, where the sulfate from barite $\left(\mathrm{BaSO}_{4}\right)$ is converted to sulfur dioxide gas $\left(\mathrm{SO}_{2}\right)$ by flash combustion at $1700{ }^{\circ} \mathrm{C}$ in an oxygen atmosphere. Measurements are calibrated using international sulfate standards NBS 127, IAEA SO5 and IAEA SO6 (relative to Vienna Canyon Diablo Troilite, hereafter VCDT, $+21.1 \%$, $+0.49 \%$, and $-34.05 \%$, respectively; Coplen et al., 2001) and an in-house synthetic $\mathrm{BaSO}_{4}$ (Sigma-Aldrich) standard (8.6\%, VCDT). Repeated measurements of the in-house standard (typically 
$>10$ measurements per run) and international standards (3-4 measurements per standard per run) yield an average reproducibility of $0.15 \%$ o (1 standard deviation $-\sigma)$.

\subsection{Statistical analysis}

The isotope data includes errors in sample-assigned ages and uncertainties of how well a single measurement represents the seawater sulfate $\delta^{34} \mathrm{~S}$ value. Note that the latter uncertainty not only includes analytical precision (which can be quantified) but also sample origin, sample handling and sample extraction. We therefore have to assume that each measurement carries an unknown error (or noise).

However, the $\delta^{34} \mathrm{~S}$ value of seawater sulfate at any given time $(t)$ depends to a certain degree on the $\delta^{34} \mathrm{~S}$ of sulfate at a given time before $(t-\Delta t)$. This allows us to apply a "local regression smoothing" technique (LOESS, Cleveland, 1979) to estimate the likely value for the $\delta^{34} \mathrm{~S}$ of sulfate at any time of interest.

We used the default LOESS module provided by the statistical software package R (R Core Team, 2012). The $95 \%$ confidence interval is calculated for each data point from the standard errors returned by the LOESS function.

\subsection{Sulfur cycle model}

We describe the sulfur cycle using the following mass conservation equation:

$$
\frac{\mathrm{d}}{\mathrm{d} t} M_{\mathrm{SO}_{4}}(t)=F_{\mathrm{wp}}(t)-F_{\mathrm{bp}}(t)+F_{\mathrm{we}}(t)-F_{\mathrm{be}}+F_{\mathrm{v}},
$$

where $M_{\mathrm{SO}_{4}}$ denotes the mass of sulfate in the ocean, calculated from the sulfate concentration and the ocean volume; $F_{\text {wp }}$ and $F_{\text {we }}$ denote the pyrite and evaporite weathering input, respectively; $F_{\mathrm{V}}$ denotes the volcanic flux, and $F_{\mathrm{bp}}$ and $F_{\text {be }}$ denote the pyrite and evaporite precipitation flux, respectively.

We can formulate a similar mass conservation equation for the respective isotopes of sulfur $\left({ }^{32} \mathrm{~S}\right.$ and $\left.{ }^{34} \mathrm{~S}\right)$, as in Eq. (2):

$$
\begin{gathered}
\frac{\mathrm{d}}{\mathrm{d} t} M_{\mathrm{SO}_{4}}^{32}(t)=F_{\mathrm{wp}}^{32} S(t)-F_{\mathrm{bp}}^{32} S(t)+F_{\mathrm{we}}^{32} S(t) \\
+F_{\mathrm{v}}^{32} S-F_{\mathrm{be}}^{32} S
\end{gathered}
$$

where $M_{\mathrm{SO}_{4}}^{32}$ denotes mass of ${ }^{32} \mathrm{~S}$ in the ocean calculated from known mass of sulfate and its isotopic composition; $F_{\mathrm{wp}}^{32} S$ and $F_{\mathrm{bp}}^{32} S$ denote ${ }^{32} \mathrm{~S}$ input from pyrite weathering and ${ }^{32} \mathrm{~S}$ removal by pyrite burial, respectively; $F_{\mathrm{V}}^{32} S$ denotes the ${ }^{32} \mathrm{~S}$ input from volcanic flux; $F_{\text {we }}^{32} S$ and $F_{\text {be }}^{32} S$ denote the ${ }^{32} \mathrm{~S}$ input from evaporite weathering and removal by evaporite precipitation, respectively.

In order to achieve an initial steady state we use modern values for the sulfur isotope composition and volume of the fluxes as boundary conditions (e.g., Berner, 1982; Kump, 1989; Hansen and Wallmann, 2003; Bottrell and Newton,
2006; see Table 1. for additional details). Note that the average isotopic composition of buried pyrite $\left(\delta^{34} \mathrm{~S}_{\text {pyrite }}\right)$ is calculated so that other fluxes are in steady state.

From steady state condition,

$\frac{\mathrm{d}}{\mathrm{d} t} M_{\mathrm{SO}_{4}}(t)=0$,

we can calculate the average $\delta^{34} S_{\text {pyrite }}$ value using Eq. (4) and Eq. (5):

$F_{\mathrm{bp}}(t)=F_{\mathrm{bp}}^{32} S(t)+F_{\mathrm{bp}}^{34} S(t)$,
$F_{\mathrm{bp}}^{34} S(t)=F_{\mathrm{we}}^{34} S(t)+F_{\mathrm{wp}}^{34} S(t)+F_{\mathrm{v}}^{34} S-F_{\mathrm{be}}^{34} S$.

This yields $\delta^{34} S_{\text {pyrite value of }}-18 \%$, which is in agreement with previous estimates (Strauss, 1997; Seal, 2006; Leavitt et al., 2013). This implies the average offset $\left(\Delta_{\text {pyr }}\right)$ between $\delta^{34} \mathrm{~S}_{\text {seawater }}$ and $\delta^{34} \mathrm{~S}_{\text {pyrite }}$ of $-40 \%$ (VCDT) which is similar to the Cenozoic average (Leavitt et al., 2013).

\subsection{Model forcing}

The objective of our model is to evaluate the effect of sea level changes on pyrite burial and weathering on the continental shelf and use these changes to track shelf sediment offloading. This requires that we consider two boxes for pyrite burial/erosion. The first box allows for pyrite burial and erosion in the shelf area as a function of the sea level, whereas the second box describes constant pyrite burial in the deep sea and pyrite erosion on continents. Our model follows the "rapid recycling" concept (Berner, 1987; see also Halevy et al., 2012) which separates inputs and outputs, to and from young and old sediment sub-reservoirs. This separation of young vs. old is geologically reasonable, because young sediments deposited in the near-shore environments are more likely to be weathered than older sediments (Berner, 1987). The novelty in our approach is that we scale fluxes into and from shelf sediments in proportion to the shelf area, as calculated from the high-resolution Quaternary sea level record (Miller et al., 2011).

We assume that up to $90 \%$ of the total amount of pyrite is buried in the continental shelf (e.g., Berner, 1982; Canfield et al., 1992; Jørgensen, 1982). In deep water environments, the supply of OM is greatly reduced, and MSR and pyrite burial rates are orders of magnitudes smaller than in the shelf. In a first approximation, we can therefore treat pyrite burial in the deep-water box as constant.

There are, however, caveats to this assumption. Pyrite burial could increase if we (a) increase the delivery of reactive $\mathrm{OM}$ to the deep ocean by increasing export production, (b) introduce anoxic conditions, (c) move coastal upwelling zones offshore during glaciations, and (d) increase input of reactive iron to deep water environments through glacial erosion, iceberg sediment delivery, etc. Although some researchers argued for increased productivity (e.g., Murray et al., 1993; Filippelli et al., 2007) this is disputed by others 
Table 1. Model fluxes and sulfur isotope ratios in the steady state.

\begin{tabular}{|c|c|c|c|}
\hline Flux & $\begin{array}{c}\text { Initial flux } \\
- \text { steady state } \\
{\left[\mathrm{mol} \mathrm{SO}_{4} \text { year }^{-1}\right]}\end{array}$ & $\begin{array}{r}\text { Isotopic } \\
\text { composition [\%o] } \\
\delta^{34} \mathrm{~S}(\mathrm{VCDT})\end{array}$ & References \\
\hline Pyrite weathering & $1.5 \times 10^{12}$ & -15 & $\begin{array}{l}\text { Kump (1989), Garrels and Lerman (1981), } \\
\text { Petsch and Berner (1998), Seal (2006), }\end{array}$ \\
\hline Evaporite weathering & $2 \times 10^{12}$ & 21 & $\begin{array}{l}\text { Kump (1989), Garrels and Lerman (1981), see } \\
\text { also Hansen and Wallmann (2003), for } \delta^{34} S_{\text {evap }} \\
\text { see Claypool et al. (1980) }\end{array}$ \\
\hline Volcanic flux & $0.34 \times 10^{12}$ & 3 & $\begin{array}{l}\text { Hansen and Wallmann (2003) and references } \\
\text { therein }\end{array}$ \\
\hline Pyrite burial & $1.6 \times 10^{12}$ & $-18^{\mathrm{a}}$ & $\begin{array}{l}\text { Bottrell and Newton (2006), Turchyn and } \\
\text { Schrag (2004), Berner (1982), Petsch and } \\
\text { Berner (1998) }\end{array}$ \\
\hline Evaporite precipitation & $2.24 \times 10^{12}$ & $22^{\mathrm{b}}$ & $\begin{array}{l}\text { Kump (1989), Garrels and Lerman (1981), } \\
\text { Petsch and Berner (1998) }\end{array}$ \\
\hline
\end{tabular}

Note: The global sulfur fluxes are not well constrained. All fluxes used to achieve steady state are scaled within the range of previously published estimates (see reference list). The initial sulfate concentration is $27 \mathrm{mmol} \mathrm{L}^{-1}$ which is in the range of estimates based on fluid inclusions in halite for late Miocene/Pliocene (Horita et al., 2002; Zimmermann, 2000; Brennan et al., 2013). ${ }^{\text {a }}$ Steady state value calculated as a function of other known fluxes (see text). ${ }^{\mathrm{b}}$ This is used for model initialization. Later on the isotope value of the respective seawater sulfate.

(e.g., Nameroff et al., 2004; Francois et al., 1997; Dean et al., 1997). On the other hand, while redox proxies support decreased oxygen levels in some parts of the deep glacial ocean (François et al., 1997; Thomson et al., 1990; Mangini et al., 2001; Dean et al., 1997), other areas, specifically continental margins, show the opposite trend (i.e., higher oxygen levels, Ganeshram et al., 2002). Overall, Pleistocene trends of deep sea oxygenation are difficult to assess because they are dependent on several factors including circulation patterns, local productivity and temperature which show a high degree of temporal and spatial variability (e.g., Jaccard et al., 2010; Keeling et al., 2010). The offshore migration of upwelling zones during lowstands may increase burial of organic matter and pyrite in the slope and abyssal regions. However, the overall impact of this migration is likely small because upwelling areas have a small areal extent and thus a modest impact on the overall organic carbon burial $(<10 \%$ Berner, 1982; Hedges and Keil, 1995; Hu and Cai, 2011). Furthermore, pyrite burial is often limited in the upwelling zones by the lack of reactive iron (e.g., Morse and Emeis, 1990; Mossmann et al., 1991; Schenau et al., 2002; Brüchert et al., 2003; Suits and Arthur, 2000). The glacial inputs of iron by glacier meltwater and icebergs are likely significantly larger than at present, but most of it is in the form of crystalline iron oxides and silicates (e.g., Poulton and Raiswell, 2002; Raiswell et al., 2006) which react with sulfide on $100 \mathrm{kyr}-$ 1 Myr timescales (Canfield et al., 1992; Raiswell and Canfield, 1998). On the other hand, the majority of reactive $\mathrm{Fe}$ is trapped in fjords/estuaries (85-90\%; Raiswell et al. 2006; Schroth et al., 2014) and thus unlikely to significantly contribute to pyrite burial in deep water environments. For the purpose of this model we therefore assume that pyrite burial in abyssal environments can be treated as constant.

Sediment offloading will also introduce pyrite and OM into the abyssal box. However, this redistributed pyrite cannot be counted twice, and thus will not alter the overall pyrite burial. The case for $\mathrm{OM}$ is however more complicated, as the additional OM will promote increased MSR. The extent of this OM support of MSR is however less clear as the remobilized OM is dominantly refractory in nature.

If sediments are quickly transferred from shelf to abyssal regions (e.g., gravity flows), OM and pyrite in redistributed sediments are highly vulnerable to oxidation due to greater oxygen penetration in deep water environments (Colley et al., 1984; Cowie et al., 1995; Thomson et al., 1998; Robinson, 2001). The process will continue until the diffusive supply of oxygen is interrupted either through deposition of pelagic sediment or another turbidite layer, which can last from a few thousand years to $>10 \mathrm{kyr}$ (Cowie et al., 1995; Thomson et al., 1998; De Lange, 1998; Robinson, 2001). While we cannot quantify the amount of pyrite oxidized in this manner, we note that it is likely a significant portion of the overall pyrite weathering, particularly during glaciations when turbidite events are common (Weaver et al., 2000; Piper and Normark, 2009; Meiburg and Kneller, 2010).

We used the sea level estimates of Miller et al. (2011) to calculate the size of the global shelf area. Sea level variations (Fig. 1a) are often modified by local signals (e.g., gravity, mantle flow, isostatic rebound). However, the use of a global mean hypsometric curve (ETOPO-5, National Geophysical Data Center, 1988) is likely to average out local signals.

We calculate the shelf area ( $A_{\mathrm{s}}$; see Fig. 1b) as a function of sea level at any given point in time using a model cu- 

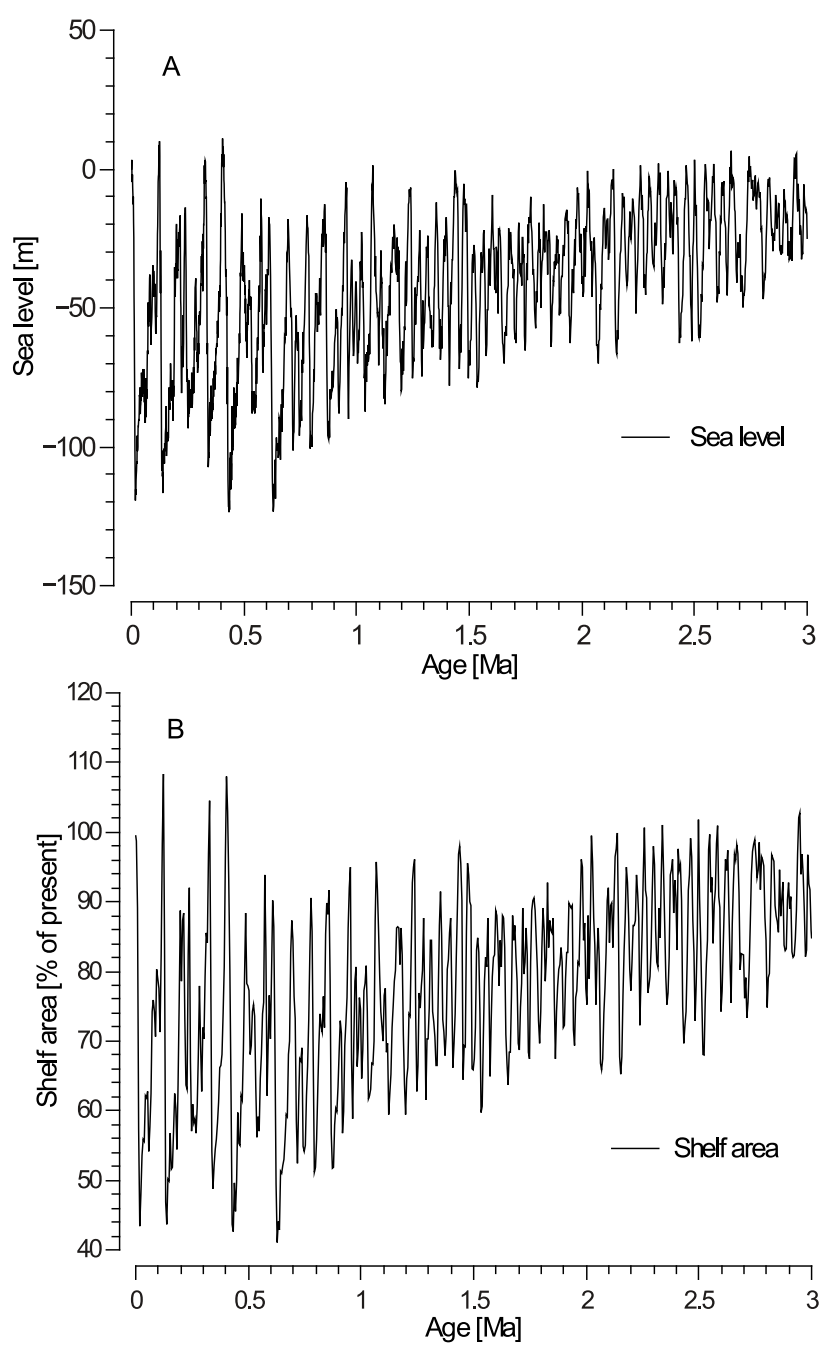

Figure 1. Sea level and shelf area estimate. (a) Sea level estimate (Miller et al., 2011). (b) Calculated shelf area using polynomial fit (Bjerrum et al., 2006) of ETOPO-5 global mean hypsometric curve.

bic polynomial fit (Eq. 6, after Bjerrum et al., 2006) of the ETOPO-5 hypsometric curve (National Geophysical Data Center, 1988):

$$
A_{\mathrm{s}}=A \times\left(1-0.307 \times z^{3}+0.624 \times z^{2}+0.43 \times z+0.99991\right),
$$

where $A$ is the area of the ocean $\sim 3.6 \times 10^{14} \mathrm{~m}^{2}$ and $z$ corresponds to the sea level (m).

The shelf area is used to force the fluxes affected by sea level change: pyrite and evaporite weathering and pyrite burial. First we divide these fluxes into two boxes. The first box corresponds to constant weathering on continents and constant pyrite burial in continental slope and pelagic environments. The second box represents pyrite and evaporite weathering and pyrite burial on the shelf and varies in proportion to calculated shelf area (Eqs. 7, 8). The pyrite weathering flux is calculated as follows:

$F_{\mathrm{wp}}=F_{\mathrm{wp}}^{o} \times\left[1+\frac{A_{\mathrm{max}}-A_{\mathrm{s}}}{A_{\mathrm{s}}}\right]$,

where $A_{\max }$ is the maximum extent of shelf area; $F_{\mathrm{wp}}$ is the calculated pyrite weathering flux corresponding to shelf change $A_{\mathrm{s}}^{o}-A_{\mathrm{s}}^{*} . F_{\mathrm{wp}}^{o}$ is the minimum pyrite weathering flux corresponding to maximum shelf extent $\left(A_{\max }\right)$. We assume $F_{\text {wp }}^{o}$ to be $90 \%$ of the steady state value calculated for the modern conditions. This assumption is based on the estimates of maximum shelf flooding area in the past $3 \mathrm{Myr}$. During times of maximum flooding the sea level may have been up to $10 \mathrm{~m}$ higher than the current sea level (Miller et al., 2011), corresponding to a $10 \%$ larger shelf area. At present some pyrite weathering takes place on this previously inundated shelf area. Therefore, we assume that during times of maximum extent of shelf inundation, pyrite weathering was lower and only $90 \%$ of that today, because pyrite rich shelf sediments were flooded.

Since shelf environments also contain large deposits of evaporites (e.g., Warren, 2006 and 2010), shelf area variations across glacial-interglacial cycles also affect evaporite weathering. Here we assume that evaporite and pyrite weathering covary and as a result of this the sulfur isotopic composition of sulfate input is steady at $\sim 5.6 \%$ VCDT, which is in line with present day riverine sulfate $\delta^{34} \mathrm{~S}$ values and Phanerozoic estimates (on average 3-8\%o VCDT; Canfield, 2013, and references therein). Evaporite weathering is thus calculated as follows:

$F_{\mathrm{we}}=F_{\mathrm{we}}^{o} \times\left[1+\frac{A_{\max }-A_{\mathrm{s}}}{A_{\mathrm{s}}}\right]$,

where $A_{\max }$ is the maximum extent of shelf area; $F_{\text {we }}$ is the calculated evaporite weathering flux corresponding to shelf change $A_{\mathrm{s}}^{o}-A_{\mathrm{s}}^{*} . F_{\mathrm{we}}^{o}$ is the minimum evaporite weathering flux corresponding to maximum shelf extent $\left(A_{\max }\right)$. We assume that $F_{\text {we }}^{o}$ is $90 \%$ of the steady state value.

The pyrite burial flux is calculated as follows Eq. (9):

$F_{\mathrm{bp}}=F_{\mathrm{bp}-\text { abyssal }}+F_{\mathrm{bp}-\text { shelf }} \times \frac{A_{\mathrm{s}}-A_{\text {min }}}{A_{\max }-A_{\min }}$,

where $F_{\mathrm{bp} \text {-abyssal }}$ corresponds to the minimum pyrite burial which takes place in slope and abyssal environments at minimum shelf extent, in this case $0.6 \times 10^{12} \mathrm{molS} \mathrm{yr}^{-1}$; $F_{\mathrm{bp}-\text { shelf }}$ is the portion of pyrite that is buried on the shelf at the maximum shelf extent $\left(A_{\max }\right)$ assumed to be $1.4 \times 10^{12} \mathrm{molS} \mathrm{yr}^{-1} ; A_{\min }$ is the minimum shelf extent. These numbers are based on present-day estimates of sulfate reduction rates and pyrite burial in sediments at different water depth (Jørgensen, 1982; Jørgensen and Kasten, 2006; Thullner et al., 2009).

When considering pyrite burial on the shelf, we distinguish between old pyrite and pyrite which can be remobilized. The former represents the total shelf storage of 
pyrite $\left(\sim 10^{19} \mathrm{molS}\right.$; Charlson et al., 1992), while the latter corresponds to the pyrite sub-reservoir in offloaded shelf sediments. Hay and Southam (1977) estimate that $5 \times 10^{21} \mathrm{~g}$ of shelf sediment was offloaded during the Pleistocene. If we take an average concentration of pyrite in pre-Holocene fine grained sediments $(0.35 \mathrm{wt} \%$; Berner, 1982), this corresponds to a pyrite reservoir of $6 \times 10^{17} \mathrm{~mol} \mathrm{~S}$. However, this estimate carries a potentially large error. Although modern observations suggest that pyrite is quickly oxidized in reworked shelf sediments (e.g., Amazon shelf; Aller et al., 1986), it is unclear if all of this eroded pyrite was oxidized. Furthermore, the measured content of pyrite sulfur in shelf sediments is highly variable $(0.1-1.5 \mathrm{wt} \%$; Berner, 1982). Therefore, we suggest that the pyrite sub-reservoir in offloaded sediments could be $6 \times 10^{17} \pm 3 \times 10^{17} \mathrm{~mol} \mathrm{~S}$ and we use this range in model runs.

The average isotopic composition of pyrite across glacialinterglacial periods is not known. The sulfur isotope fractionation is negatively correlated with sedimentation rate (e.g., Goldhaber and Kaplan, 1975), and the recent work by Leavitt et al. (2013) has identified a negative correlation between $\delta^{34} S_{\text {pyrite }}$ value and shelf area. Since the shelf area has changed dramatically across glacial-interglacial cycles, it is likely that the offset $\left(\Delta_{\text {pyr }}\right)$ between $\delta^{34} S_{\text {seawater }}$ and $\delta^{34} S_{\text {pyrite }}$ values has also changed. Here we calculate variable $\Delta_{\text {pyr }}$ as follows:

$\Delta_{\mathrm{pyr}}=-50+15 \times \frac{A_{\mathrm{s}}-A_{\text {min }}}{A_{\max }-A_{\min }}$,

where $A_{\mathrm{s}}$ is shelf area at any given time, $A_{\max }$ and $A_{\min }$ are the maximum and minimum extents of shelf area, respectively. This gives $\Delta_{\text {pyr }}$ of $-50 \%$ o for the most severe glaciations (lowest shelf extent) and 35\% for the maximum shelf inundation, which is in line with the Leavitt et al. (2013) $\Delta_{\text {pyr }}$ range of estimates for the past $200 \mathrm{Myr}$.

To test the impact of these temporal variations of $\Delta_{\text {pyr }}$, we also run our model with "fixed" $\Delta_{\text {pyr }}$ of $-40 \%$ (our steady state value).

\subsection{Sensitivity analysis}

The inputs and outputs in the sulfur cycle are not well constrained (Bottrell and Newton, 2006). Estimates for modern pyrite burial vary between 30 and $90 \%$ of the total sulfur burial with the remainder being buried as gypsum or anhydrite (e.g., Canfield, 2004; Kampschulte and Strauss, 2004; Halevy et al., 2012; Canfield, 2013; Tostevin et al., 2014). Similarly, the average sulfur isotopic composition of recently precipitated pyrite is thought to be between -40 and $-10 \%$ o (VCDT) (Strauss, 1997; Johnston et al., 2008).

Also note that the burial of organic sulfur is poorly constrained (Werne et al., 2004). Although, it is generally considered to be minor compared to pyrite burial (e.g., Goldhaber, 2003; Werne et al., 2004), in some environments (e.g., the Peru shelf, the Miocene Monterey Formation, marine sapropels) it is the dominant form of reduced solid sulfur compounds (e.g., Mossmann et al., 1991; Canfield et al., 1998; Suits and Arthur, 2000).

Although the estimates of the respective sulfur fluxes and their isotopic composition vary considerably, the S-isotope record of the $\sim 40-50 \mathrm{Ma}$, prior to the Quaternary, is essentially stable (Paytan et al., 1998). This implies that the sulfur inputs and outputs must have been in isotopic balance, irrespective of their actual magnitude (Kurtz et al., 2003). To evaluate whether our model is sensitive to uncertainties in flux estimates, we run model experiments assuming twice and a half the flux estimates used above (see Table 1) and using the same forcing. For each setup, we run our model twice: first time with "fixed" $\Delta_{\mathrm{pyr}}$ of $-40 \%$ (our steady state value) and then with variable $\Delta_{\mathrm{pyr}}$.

\section{Results and Discussion}

Our results show that between 3 and $\sim 1.5 \mathrm{Ma}$ the seawater $\delta^{34} \mathrm{~S}_{\mathrm{SO}_{4}}$ values fluctuate around $\sim 22 \%$ (VCDT) with a standard deviation $(1 \sigma)$ of $0.2 \%$. In the interval between 1.5 and $0.7 \mathrm{Ma}$ we observe a steady decline from $\sim 22$ to $20.7 \%$ o (VCDT) (Fig. 2). This minimum is followed by an upwards trend from $20.7 \%$ (VCDT) at $0.7 \mathrm{Ma}$ to $21.1 \%$ (VCDT) at $0.6 \mathrm{Ma}$. In the past $0.3 \mathrm{Myr}$ there is a decline from 21.1 to $\sim 20.7 \%$ o (VCDT) in the most recent sediments (Fig. 2; see Table A1 in Appendix for full list of samples).

\subsection{Causes of seawater sulfate $\delta^{34} \mathrm{~S}$ change}

Considering the long residence time of sulfate in the ocean $\left(10^{7} \mathrm{yr}\right.$; Jørgensen and Kasten, 2006 ), a $-1 \%$ shift between 1.5 and $0.7 \mathrm{Ma}$, implies a massive change in the balance of the sulfur input/output fluxes. Possible explanations include (a) an order of magnitude increase of volcanic and hydrothermal S release, (b) a drastic increase in pyrite weathering, and (c) a massive decrease in pyrite burial. An order of magnitude increase of volcanic S input is incompatible with the geological record which shows no evidence for intensification of volcanic activity in the Pleistocene compared to the earlier periods of the Cenozoic (Kaiho and Saito, 1994; Mason et al., 2004; Cogné and Humler, 2006; White et al., 2006).

Pyrite weathering could have been affected by changes in continental erosion rates in the past $3 \mathrm{Myr}$ (e.g., Raymo et al., 1988). However, recent evidence suggests that these changes were minor (e.g., Foster and Vance, 2006). Nonetheless, pyrite weathering is not restricted to the continental interiors, but happens each time marine sediments are exposed to erosion.

Glacially induced sea level drops will expose large swaths of previously ocean-covered shelf areas to subaerial weathering and erosion. Coincidentally, the shallow shelf is also the location of the highest pyrite burial rates (Jørgensen, 1982). First-order approximations show that shelf-area- 


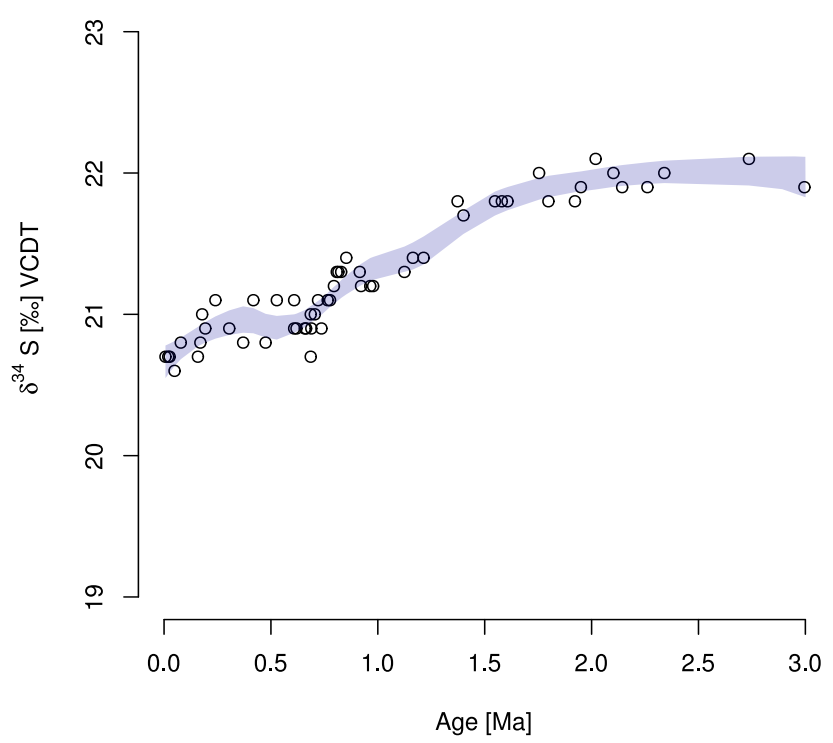

Figure 2. Seawater sulfate $\delta^{34} \mathrm{~S}$ value. The circles denote the measured seawater sulfate $\delta^{34} \mathrm{~S}$ value, the shaded area the $95 \%$ confidence interval of a LOESS approximation of the "true" $\delta^{34} \mathrm{~S}_{\mathrm{SO}_{4}}$ value.

related changes in pyrite burial/weathering rates are indeed large enough to explain the observed variations in the marine sulfate $\delta^{34} \mathrm{~S}$ value.

In this context, it is interesting to note that the timing of the $\delta^{34} \mathrm{~S}$ value shift roughly coincides with increasing amplitude and decreasing frequency of glacial-interglacial cycles (Lisiecki and Raymo, 2005; Clark et al., 2006). In this period the gradual increase in ice volume during glaciations resulted in larger sea level fluctuations (up to $150 \mathrm{~m}$; Fig. 1a, Miller et al., 2011) exposing vast areas of continental shelf to weathering and erosion which previously remained fully marine for tens of millions of years (Clark et al., 2006).

In the following we use a box model to investigate the hypothesis that the changes in the $\delta^{34} \mathrm{~S}$ value of marine sulfate are driven by changes in pyrite burial and weathering in the shelf area.

We first calculate the ocean-covered shelf area as a function of sea level using the sea level estimates by Miller et al. (2011). In a subsequent step we calculate burial/weathering fluxes as a function of shelf area (see Methods section for a detailed description). For example, if sea level drops by $100 \mathrm{~m}$ (typical for the glaciations in the past $1 \mathrm{Myr}$; see Miller et al., 2011) the shelf area is reduced by $50 \%$. The exposure and erosion of previously inundated shelf results in the oxidation of sulfide minerals (i.e., pyrite), which increases pyrite weathering from $1.5 \times 10^{12} \mathrm{~mol} \mathrm{Syr}^{-1}$ at steady state to $2.8 \times 10^{12} \mathrm{~mol} \mathrm{Syr}^{-1}$. At the same time, pyrite burial decreases from $1.6 \times 10^{12}$ to $0.8 \times 10^{12} \mathrm{~mol} \mathrm{~S} \mathrm{yr}^{-1}$ (for model forcing see Figs. 3 and also A4-A5 for sensitivity runs).
Increased pyrite weathering during lowstands depletes the shelf pyrite sub-reservoir, which we estimate to be $6 \times 10^{17} \pm 3 \times 10^{17} \mathrm{~mol} \mathrm{~S}$ (see Methods). We run a sensitivity analysis to determine how model output changes in this region of shelf pyrite sub-reservoir input parameter uncertainty.

Although the recent work by Leavitt et al. (2013) suggests that $\Delta_{\text {pyr }}$ increases with decreasing shelf area and vice versa on timescales of $10^{7}-10^{9} \mathrm{yr}$, the glacial-interglacial variations are not constrained. Due to long residence time of sulfate $\left(10^{7} \mathrm{yr}\right)$ it is unclear if $\Delta_{\text {pyr }}$ changes on this timescale affect seawater sulfate $\delta^{34} \mathrm{~S}$. We explore the impact of $\Delta_{\text {pyr }}$ temporal variations by comparing model outputs produced assuming "fixed" $\Delta_{\text {pyr }}\left(-40 \%\right.$ ) or variable $\Delta_{\text {pyr }}$, calculated in inverse proportion to the shelf area and within the range of Phanerozoic estimates in Leavitt et al. (2013) (see Methods for details and Fig. 4 for variable $\Delta_{\text {pyr }}$ ).

We start our model at $3 \mathrm{Ma}$ (late Pliocene) and forward the resulting sulfur isotopic composition of seawater sulfate as a function of the sea level estimates published by Miller et al. (2011). Our model captures the shape and magnitude of the $\delta^{34} \mathrm{~S}$ signal quite well (Fig. 5). Specifically, the decline of $\delta^{34} \mathrm{~S}$ values in the past $1.5 \mathrm{Myr}$ is well represented. This suggests that, during this time interval, larger sea level fluctuation of up to $-150 \mathrm{~m}$ (Lisiecki and Raymo 2005; Clark et al., 2006; Miller et al., 2011) drastically increased the transfer of shelf sediments into the deep ocean.

During the interglacial periods, sea level rise creates large accommodation volumes, but Hay and Southam (1977) proposed that the creation of accommodation space outstripped sediment supply, resulting in a net loss of $5 \times 10^{21} \mathrm{~g}$ of shelf sediment during the Quaternary. This interpretation is supported by our $\delta^{34} \mathrm{~S}$ data, which suggest that the balance between pyrite weathering and pyrite burial shifts in favor of pyrite weathering with increasing sea level variations during the Middle Pleistocene.

The cumulative pyrite weathering is, however, constrained by variations of seawater sulfate $\delta^{34} \mathrm{~S}$. Interestingly, the steady decline of the $\delta^{34} \mathrm{~S}$ isotope values appears to slow down or to stop around $\sim 700 \mathrm{ka}$ (Fig. 2). If we accept the premise that the pyrite burial and weathering are linked to sedimentation and subaerial shelf erosion, the stabilization of seawater sulfate $\delta^{34} \mathrm{~S}$ implies that sediment offloading has come to an end or, in other words, shelf sedimentation and erosion dynamics must have reached a new equilibrium adapted to the climate driven $100 \mathrm{kyr}$ sea level cycles.

The model output is affected by the initial size of pyrite shelf sub-reservoir (Fig. 5). The mean estimate for pyrite subreservoir parameter $\left(6 \times 10^{17} \mathrm{~mol} \mathrm{~S}\right)$ produces model output within a $95 \%$ confidence interval of $\delta^{34} \mathrm{~S}$ data. Assuming the low estimate of $3 \times 10^{17} \mathrm{~mol} \mathrm{~S}$, the model output undershoots the data because the shelf pyrite sub-reservoir is quickly depleted (Fig. 5). On the other hand, if we use the higher shelf pyrite sub-reservoir estimate $\left(9 \times 10^{17} \mathrm{~mol} \mathrm{~S}\right)$, 

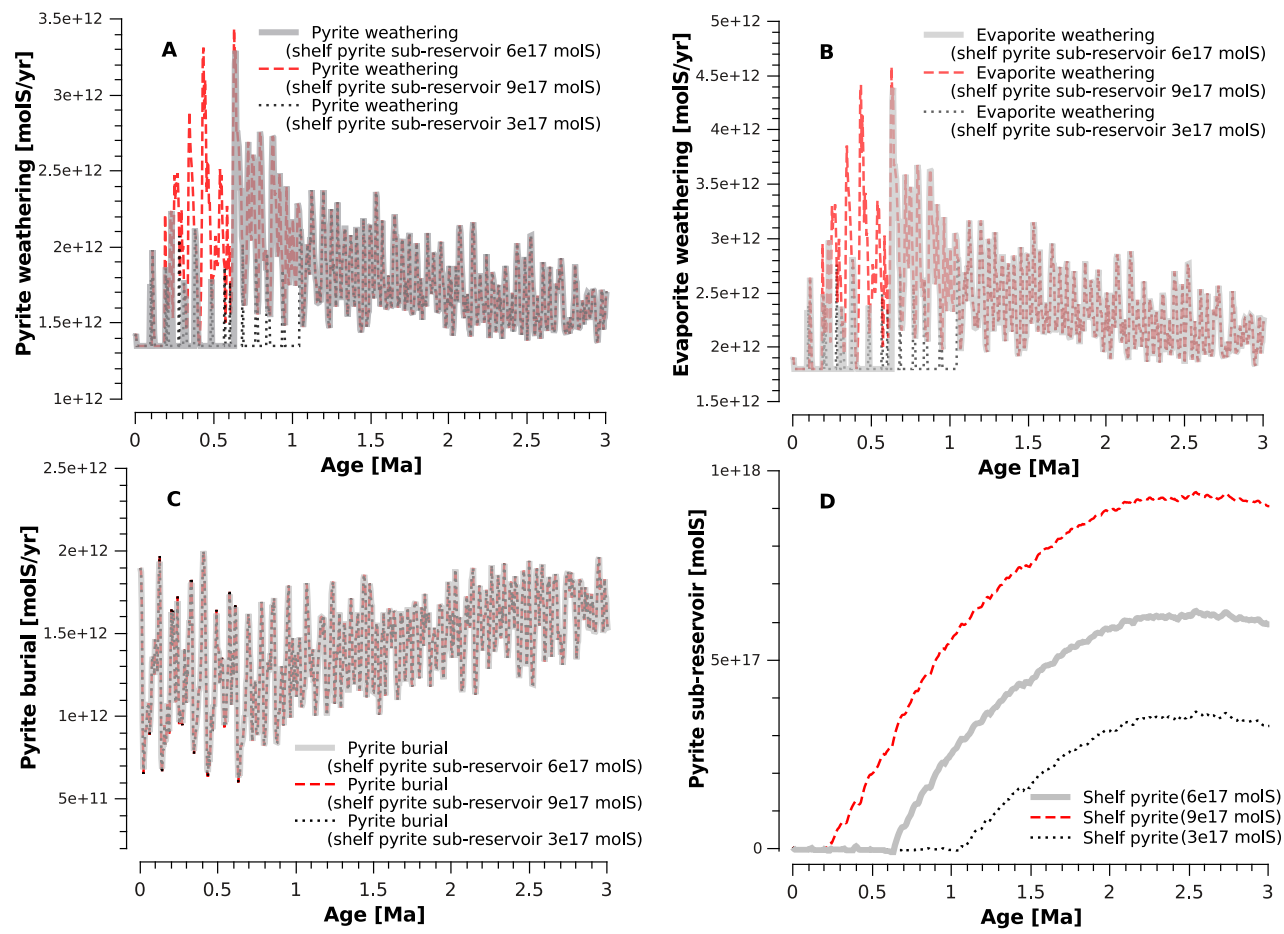

Figure 3. Model forcing. (a) Pyrite weathering. (b) Evaporite weathering. (c) Pyrite burial. (d) Pyrite reservoir on the shelf.

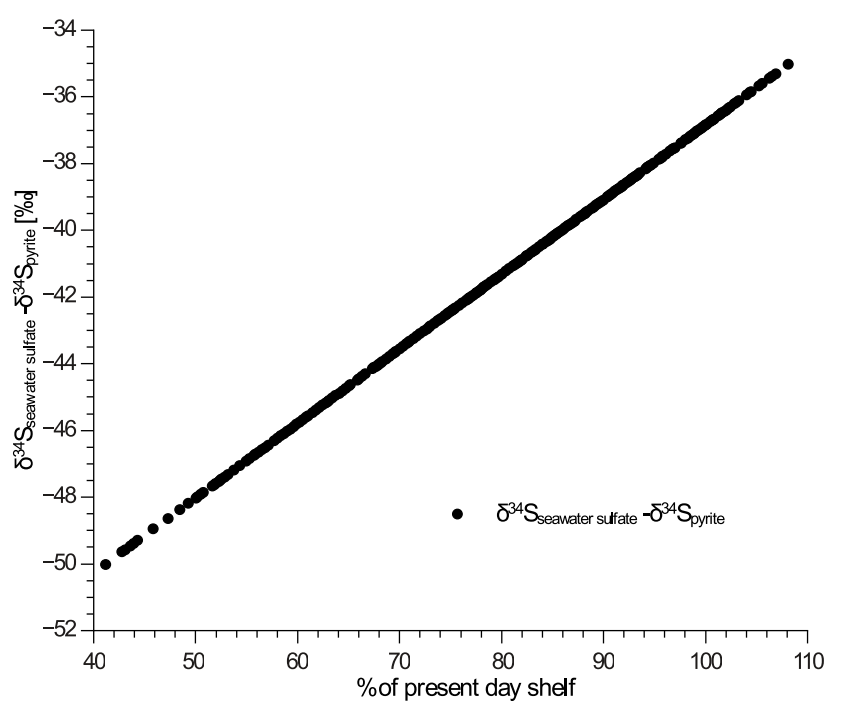

Figure 4. Sulfur isotope offset between contemporary seawater sulfate and pyrite $\left(\Delta_{\mathrm{pyr}}-\right.$ see text for details) vs. shelf area.

the model output exceeds the measured seawater sulfate $\delta^{34} \mathrm{~S}$ drop (Fig. 5).

The model outputs are almost identical whether we use "fixed" or variable $\Delta_{\text {pyr }}$, which suggests that our model is not sensitive to changes of $\Delta_{\text {pyr }}$ (see Fig. 5). This is corroborated by sensitivity test involving only variable $\Delta_{\text {pyr }}$, which produced constant output with a small positive shift in the past 1 Myr (Fig. A1). However, we are not arguing that $\Delta_{\text {pyr }}$ was constant throughout the Quaternary. Environmental factors controlling $\Delta_{\text {pyr }}$ (sedimentation rate, areal extent of shelf environments; Leavitt et al., 2013) have changed during this period, which caused both increase and decrease of $\Delta_{\text {pyr }}$. For example, during interglacials $\Delta_{\text {pyr }}$ could have been $-35 \%$, while during glacials it could have fallen to $-50 \%$ o (see Fig. 4). Since $\Delta_{\text {pyr }}$ fluctuated in both directions, the average for the whole Quaternary was similar to our "fixed" value of $-40 \%$. While better temporal understanding of $\Delta_{\text {pyr }}$ variations during the Quaternary would certainly improve our interpretation, it is unlikely that $\Delta_{\text {pyr }}$ controlled seawater sulfate $\delta^{34} \mathrm{~S}$.

In our model, we consider pyrite burial in abyssal regions as constant across glacial-interglacial cycles. However, this may not be the case, as pyrite burial during glaciations can be affected by increased OM burial, emergence of bottom water anoxia, migration of upwelling zones or by higher iron input (see Sect. 3.4 for more details). Higher pyrite burial during glacial periods, for any of these reasons, would have to be compensated by increased pyrite weathering. While this cannot be completely excluded, we note that the change of the seawater sulfate $\delta^{34} \mathrm{~S}$ value due to glacial-interglacial variations of pyrite burial alone is $\sim 30 \%$ of the overall $\delta^{34} \mathrm{~S}$ shift (Fig. A2 in Appendix). Since pyrite burial in deep ocean is small ( $\sim 10 \%$ of the overall pyrite burial; Berner, 1982; Canfield et al., 1992; Jørgensen, 1982) any change of this sink would likely have a minor impact on the seawater sul- 


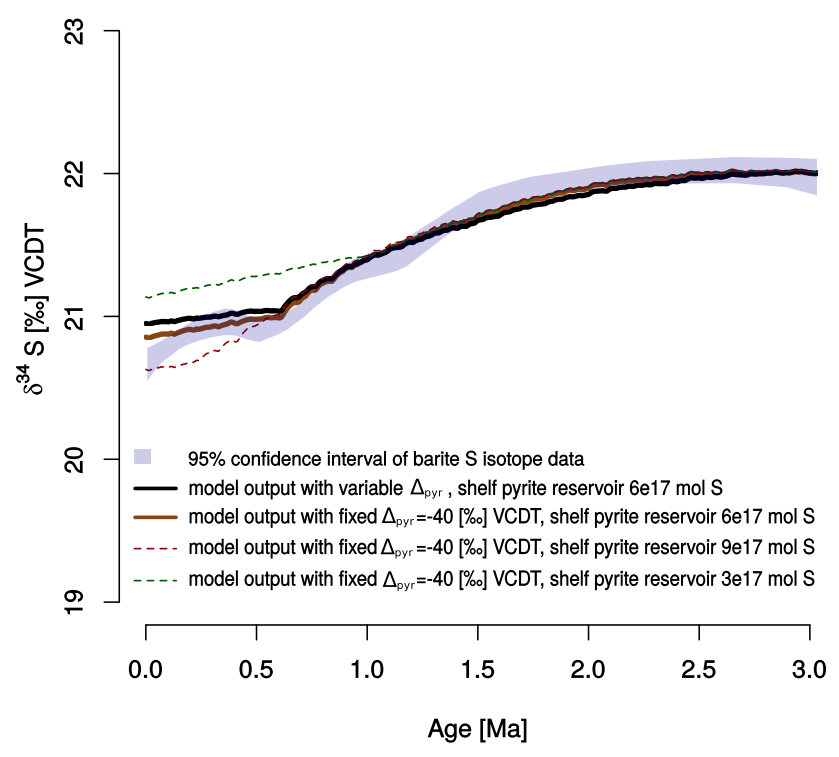

Figure 5. Model output - seawater sulfate $\delta^{34} \mathrm{~S}$ value. Brown solid line - model output with constant offset of $-40 \%$ o between $\delta^{34} \mathrm{~S}_{\text {seawater }}$ and $\delta^{34} \mathrm{~S}_{\text {pyrite }}$ values. Grey solid line - model output with variable offset between $\delta^{34} \mathrm{~S}_{\text {seawater }}$ and $\delta^{34} \mathrm{~S}_{\text {pyrite }}$ values (see Fig. 3). Red dashed line - model output with constant $\Delta_{\text {pyr }}$ offset and $50 \%$ larger shelf pyrite sub-reservoir. Green dashed line - model output with constant $\Delta_{\text {pyr }}$ offset and $50 \%$ smaller shelf pyrite sub-reservoir. The shaded area is the $95 \%$ confidence interval of a LOESS approximation of the "true" $\delta^{34} \mathrm{~S}_{\mathrm{SO}_{4}}$ value.

fate $\delta^{34} \mathrm{~S}$ value. Therefore, it is unlikely that increased pyrite burial in the abyssal plain significantly counteracted the effect of sediment offloading.

Sensitivity model runs assuming initial fluxes at twice and half the steady state values show first-order agreement with $\delta^{34} \mathrm{~S}$ data in the past $2 \mathrm{Myr}$, which supports our argument that shelf area variations during the Quaternary control seawater sulfate $\delta^{34} \mathrm{~S}$ through associated impacts on pyrite weathering and burial. However, the selection of initial fluxes and pyrite shelf sub-reservoir affects the shape of the resulting model output (Fig. A3 in Appendix).

Sensitivity runs assuming initial fluxes at half steady state lag behind the isotope record and undershoot $\delta^{34} \mathrm{~S}$ data regardless of the size of the shelf pyrite sub-reservoir (Fig. A3a, b; for forcing see A4). These damped model outputs are consistent with a traditional view of the sulfur cycle, which underlines that large and sluggish seawater sulfate reservoir changes slowly in response to the long-term changes of small sulfur fluxes (e.g., Kurtz et al., 2003). While this standpoint is valid for long-term changes of seawater sulfate $\delta^{34} \mathrm{~S}(10-100 \mathrm{Myr}$ timescales), it is inconsistent with the short-term variations (<1 to 5 Myr) (e.g., Kurtz et al., 2003; Wortmann and Chernyavsky, 2007; Wortmann and Paytan, 2012; Halevy et al., 2012). During these short intervals, large increase of sulfate inputs and outputs significantly exceeds long-term average values. Since our $\delta^{34} \mathrm{~S}$ record also suggests massive short-term imbalance between sulfur inputs and outputs, we argue that the initial fluxes at half the steady state value, although conceivable, are likely not representative of the Quaternary sulfur cycle.

The model runs assuming initial fluxes at twice the steady state values fall within the $95 \%$ confidence interval of $\delta^{34} \mathrm{~S}$ data if we assume the shelf pyrite sub-reservoir of $9 \times 10^{17} \mathrm{~mol} \mathrm{~S}$ and undershoot the data with the shelf pyrite sub-reservoir of $3 \times 10^{17} \mathrm{~mol} \mathrm{~S}$ (see Fig. A3c and d). The fluxes calculated in these sensitivity runs are at the higher end of previously published values (Fig. A5; for comparison with similar fluxes see estimate of glacial pyrite weathering in Turchyn and Schrag, 2004). Therefore, we posit that they constrain the upper limit of the shelf pyrite subreservoir which is approximately $9 \times 10^{17} \mathrm{~mol} \mathrm{~S}$. Together with our main model run (see Figs. 3 and 5) this suggests that glacial shelf sediment erosion resulted in oxidation between $6 \times 10^{17}$ and $9 \times 10^{17} \mathrm{~mol}$ of pyrite $\mathrm{S}$ during the Quaternary.

\subsection{Pyrite oxidation and the carbon cycle}

A massive increase of pyrite weathering implied by our results has important implications on the carbon cycle. Namely, pyrite weathering produces very strong sulfuric acid which dissolves carbonates (e.g., Spence and Telmer, 2005; Calmels et al., 2007). Since continental shelf sediments are rich in carbonates (de Haas et al., 2002) the production of sulfuric acid is likely balanced by carbonate dissolution, which delivers dissolved inorganic carbon (DIC) into the oceanatmosphere system. Per each mole, of sulfate two moles of DIC are transferred to the ocean (Torres et al., 2014) (Reaction R1).

$2 \mathrm{CaCO}_{3}+\mathrm{H}_{2} \mathrm{SO}_{4} \rightarrow 2 \mathrm{Ca}^{2+}+2 \mathrm{HCO}_{3}^{-}+\mathrm{SO}_{4}^{2-}$

Therefore, pyrite weathering effectively increases DIC storage in the ocean (Torres et al., 2014). If integrated over the entire period of the $\delta^{34} \mathrm{~S}$ value shift, pyrite oxidation results in a net transfer of $14000-21000 \mathrm{PgC}$ or about a third to a half of deep ocean DIC storage.

\section{Conclusions}

This study shows that the intensification of Quaternary glaciations in the past $1.5 \mathrm{Myr}$ and concomitant periodic changes in shelf area likely affected the balance of weathering fluxes of sulfate/sulfide and the burial of pyrite. We propose that during glacial periods, pyrite weathering drastically increases as a result of subaerial shelf erosion and that the increased erosion rates are not fully compensated by increased pyrite burial during sea level highstands.

The declining seawater $\delta^{34} \mathrm{~S}$ values support the idea that the transition to the climate driven $100 \mathrm{kyr}$ sea level variations resulted in a net reduction of shelf sediment vol- 
ume (i.e., the so-called "shelf sediment offloading"; Hay and Southam, 1977).

Our data show that the steady decline in the seawater $\delta^{34} \mathrm{~S}$ values stops around $700 \mathrm{ka}$. We consider it likely that this stabilization indicates the termination of the massive net "sediment offloading" (Hay and Southam, 1977) and heralds a new equilibrium between shelf erosion during sea level lowstands and sediment resupply during sea level highstands.
The resuspension of previously deposited sediments oxidized large amounts of pyrite back to sulfate. Our model results suggest that this would have increased the marine sulfate concentration by $\sim 1-3 \mathrm{mM}$ in good agreement with sulfate concentration estimates based on fluid inclusions (Brennan et al., 2013) and estimates of the ocean alkalinity based on boron isotopes (Hoenisch et al., 2009). Furthermore, it is likely that shelf sediment offloading may have impacted additional elements that are predominantly buried in the shelf sediments such as phosphorus and carbon (e.g., Berner, 1982; Wollast, 1991; Ruttenberg, 2003) with possible implications to their biogeochemical cycles as well as ocean productivity. 
Appendix A: Sample list, model results and forcing of sensitivity runs

Table A1. Sample list with sulfur isotope results.

\begin{tabular}{|c|c|c|c|c|c|c|c|c|c|}
\hline Leg & Site & Hole & Core & Section & Top $(\mathrm{cm})$ & Bottom $(\mathrm{cm})$ & Depth (m b.s.f.) & Age [Ma] & $\delta^{34} \mathrm{~S}[\% o]$ \\
\hline 138 & 851 & B & 1 & 1 & 41 & 42 & 0.41 & 0.020 & 20.7 \\
\hline 138 & 851 & B & 1 & 1 & 55 & 57 & 0.55 & 0.026 & 20.7 \\
\hline 138 & 851 & B & 1 & 1 & 106 & 108 & 1.06 & 0.049 & 20.6 \\
\hline 138 & 851 & B & 1 & 1 & 146 & 148 & 1.46 & 0.066 & 20.7 \\
\hline 138 & 851 & B & 1 & 2 & 17 & 19 & 1.67 & 0.078 & 20.8 \\
\hline 138 & 851 & B & 1 & 2 & 137 & 139 & 2.87 & 0.158 & 20.7 \\
\hline 138 & 851 & B & 1 & 2 & 147 & 149 & 2.97 & 0.170 & 20.8 \\
\hline 138 & 851 & B & 1 & 3 & 8 & 10 & 3.08 & 0.178 & 21.0 \\
\hline 138 & 851 & B & 1 & 3 & 33 & 35 & 3.33 & 0.193 & 20.9 \\
\hline 138 & 851 & B & 1 & 3 & 101 & 103 & 4.01 & 0.240 & 21.1 \\
\hline 138 & 849 & B & 2 & 1 & 100 & 104 & 7.70 & 0.305 & 20.9 \\
\hline 138 & 849 & B & 2 & 3 & 42 & 46 & 10.12 & 0.375 & 20.8 \\
\hline 138 & 851 & B & 1 & 5 & 85 & 90 & 6.85 & 0.418 & 21.1 \\
\hline 138 & 849 & B & 2 & 5 & 5 & 10 & 12.75 & 0.475 & 20.8 \\
\hline 138 & 851 & B & 2 & 1 & 75 & 80 & 8.25 & 0.528 & 21.1 \\
\hline 138 & 851 & B & 2 & 2 & 22 & 24 & 9.22 & 0.609 & 21.1 \\
\hline 138 & 851 & B & 2 & 2 & 22 & 24 & 9.22 & 0.609 & 20.9 \\
\hline 138 & 851 & B & 2 & 2 & 34 & 36 & 9.34 & 0.619 & 20.9 \\
\hline 138 & 851 & B & 2 & 2 & 130 & 132 & 10.3 & 0.659 & 20.9 \\
\hline 138 & 851 & B & 2 & 2 & 144 & 146 & 10.44 & 0.665 & 20.9 \\
\hline 138 & 851 & B & 2 & 3 & 48 & 50 & 10.98 & 0.686 & 20.7 \\
\hline 138 & 851 & B & 2 & 3 & 48 & 50 & 10.98 & 0.686 & 21.0 \\
\hline 138 & 851 & B & 2 & 3 & 56 & 58 & 11.06 & 0.689 & 20.9 \\
\hline 138 & 851 & B & 2 & 3 & 104 & 106 & 11.54 & 0.705 & 21.0 \\
\hline 138 & 851 & B & 2 & 3 & 144 & 146 & 11.94 & 0.720 & 21.1 \\
\hline 138 & 851 & B & 2 & 4 & 18 & 20 & 12.18 & 0.736 & 20.9 \\
\hline 138 & 851 & B & 2 & 4 & 66 & 68 & 12.66 & 0.765 & 21.1 \\
\hline 138 & 851 & B & 2 & 4 & 84 & 86 & 12.84 & 0.776 & 21.1 \\
\hline 138 & 851 & B & 2 & 4 & 116 & 118 & 13.16 & 0.795 & 21.2 \\
\hline 138 & 851 & B & 2 & 4 & 138 & 140 & 13.38 & 0.808 & 21.3 \\
\hline 138 & 851 & B & 2 & 4 & 146 & 148 & 13.46 & 0.815 & 21.3 \\
\hline 138 & 851 & B & 2 & 5 & 13 & 15 & 13.63 & 0.828 & 21.3 \\
\hline 138 & 851 & B & 2 & 5 & 56 & 58 & 14.06 & 0.852 & 21.4 \\
\hline 138 & 851 & B & 2 & 6 & 38 & 40 & 15.38 & 0.915 & 21.3 \\
\hline 138 & 851 & B & 2 & 6 & 49 & 51 & 15.49 & 0.922 & 21.2 \\
\hline 138 & 851 & B & 2 & 6 & 122 & 124 & 16.22 & 0.964 & 21.2 \\
\hline 138 & 851 & B & 2 & 6 & 145 & 147 & 16.45 & 0.978 & 21.2 \\
\hline 138 & 851 & B & 3 & 1 & 55 & 57 & 17.55 & 1.124 & 21.3 \\
\hline 138 & 851 & B & 3 & 1 & 122 & 124 & 18.22 & 1.164 & 21.4 \\
\hline 138 & 851 & B & 3 & 2 & 44 & 46 & 18.94 & 1.214 & 21.4 \\
\hline 138 & 849 & $\mathrm{D}$ & 4 & 1 & 54 & 56 & 33.04 & 1.373 & 21.8 \\
\hline 138 & 851 & B & 3 & 4 & 130 & 135 & 22.8 & 1.401 & 21.7 \\
\hline 138 & 851 & B & 3 & 6 & 90 & 95 & 25.4 & 1.548 & 21.8 \\
\hline 138 & 849 & D & 4 & 4 & 68 & 70 & 37.68 & 1.580 & 21.8 \\
\hline 138 & 851 & B & 3 & 7 & 28 & 30 & 26.28 & 1.607 & 21.8 \\
\hline 138 & 851 & B & 4 & 1 & 97 & 99 & 27.47 & 1.754 & 22.0 \\
\hline 138 & 849 & $\mathrm{C}$ & 5 & 2 & 103 & 105 & 41.53 & 1.798 & 21.8 \\
\hline 138 & 849 & D & 5 & 3 & 61 & 63 & 45.61 & 1.928 & 21.8 \\
\hline 138 & 851 & B & 4 & 3 & 96 & 98 & 30.46 & 1.950 & 21.9 \\
\hline 138 & 851 & B & 4 & 4 & 75 & 77 & 31.75 & 2.019 & 22.1 \\
\hline 138 & 851 & B & 4 & 5 & 87 & 89 & 33.37 & 2.102 & 22.0 \\
\hline 138 & 849 & D & 6 & 1 & 108 & 110 & 52.58 & 2.143 & 21.9 \\
\hline 138 & 849 & D & 6 & 3 & 63 & 65 & 55.13 & 2.261 & 21.9 \\
\hline 138 & 849 & D & 6 & 4 & 108 & 110 & 57.08 & 2.340 & 22.0 \\
\hline 138 & 849 & D & 7 & 5 & 16 & 18 & 67.16 & 2.736 & 22.1 \\
\hline 138 & 849 & $\mathrm{D}$ & 8 & 1 & 112 & 114 & 71.62 & 2.976 & 21.9 \\
\hline
\end{tabular}




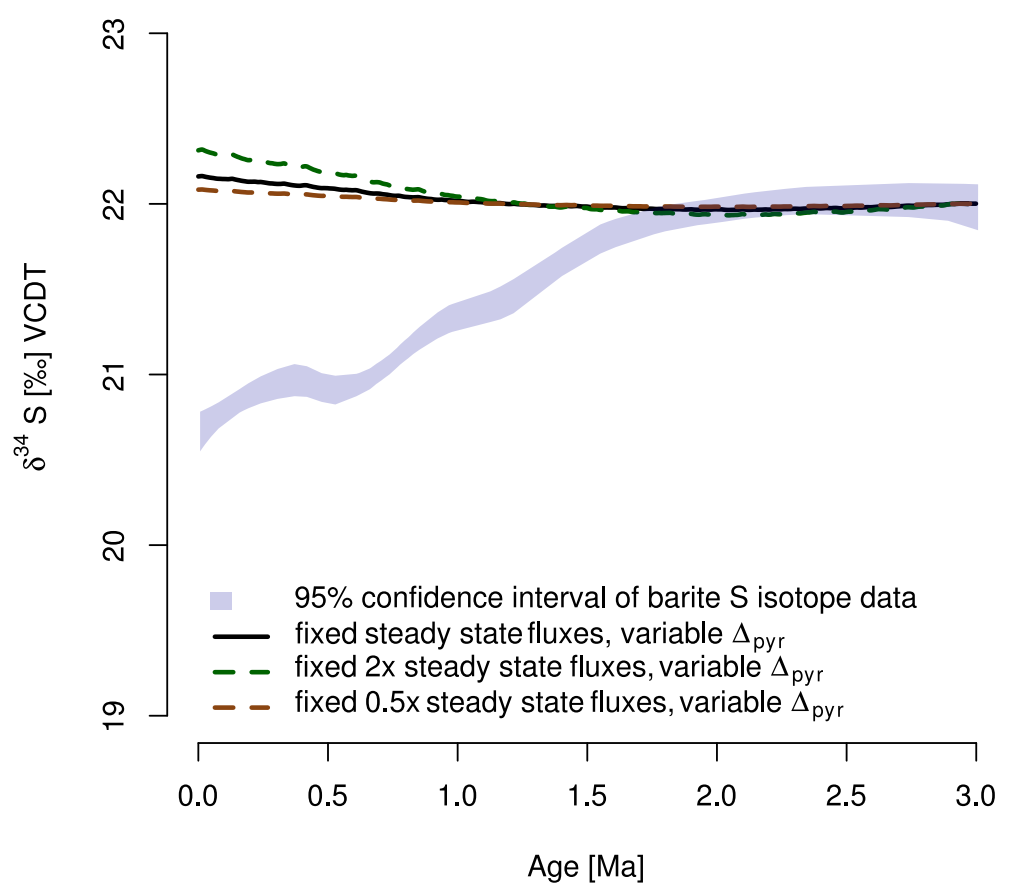

Figure A1. Model output using variable $\Delta_{\text {pyr }}$. Black solid line - model output produced assuming constant steady state fluxes and variable $\Delta_{\text {pyr }}$. Green dashed line - model output produced assuming constant fluxes at $200 \%$ steady state values and variable $\Delta_{\text {pyr. }}$ Brown dashed line - model output produced assuming constant fluxes at $50 \%$ steady state values and variable $\Delta_{\text {pyr }}$. The shaded area represents the $95 \%$ confidence interval of a LOESS approximation of the "true" $\delta^{34} \mathrm{~S}_{\mathrm{SO}_{4}}$ value. Note that the size of pyrite reservoir in these model experiments remains the same because input and output fluxes are kept constant.

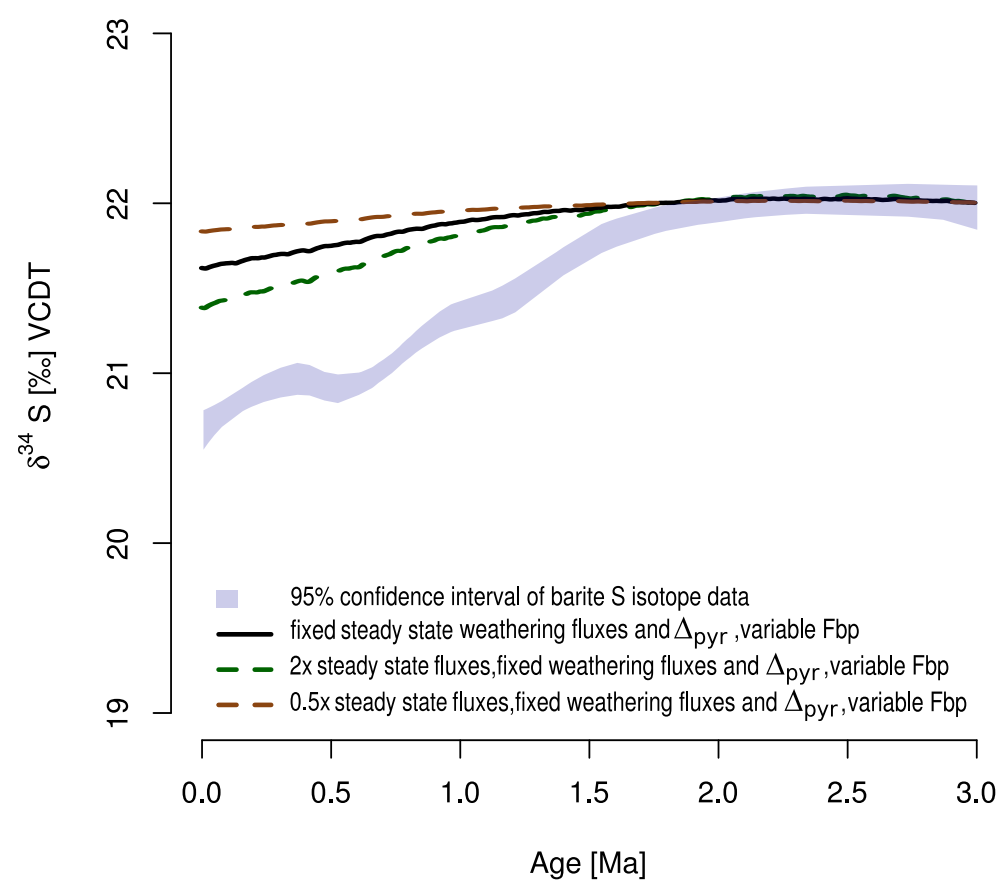

Figure A2. Model output with variable pyrite burial and fixed weathering fluxes and $\Delta_{\text {pyr }}$. Black solid line - model output produced assuming initial fluxes at steady state values, variable pyrite burial and fixed weathering fluxes and $\Delta_{\text {pyr }}$. Green dashed line - model output produced assuming initial fluxes at $200 \%$ steady state values, variable pyrite burial and fixed weathering fluxes and $\Delta_{\text {pyr }}$. Brown dashed line - model output produced assuming initial fluxes at $50 \%$ steady state values, variable pyrite burial, fixed weathering fluxes and $\Delta_{\text {pyr }}$. The shaded area represents the $95 \%$ confidence interval of a LOESS approximation of the "true" ${ }^{34} \mathrm{~S}_{\mathrm{SO}_{4}}$ composition. 

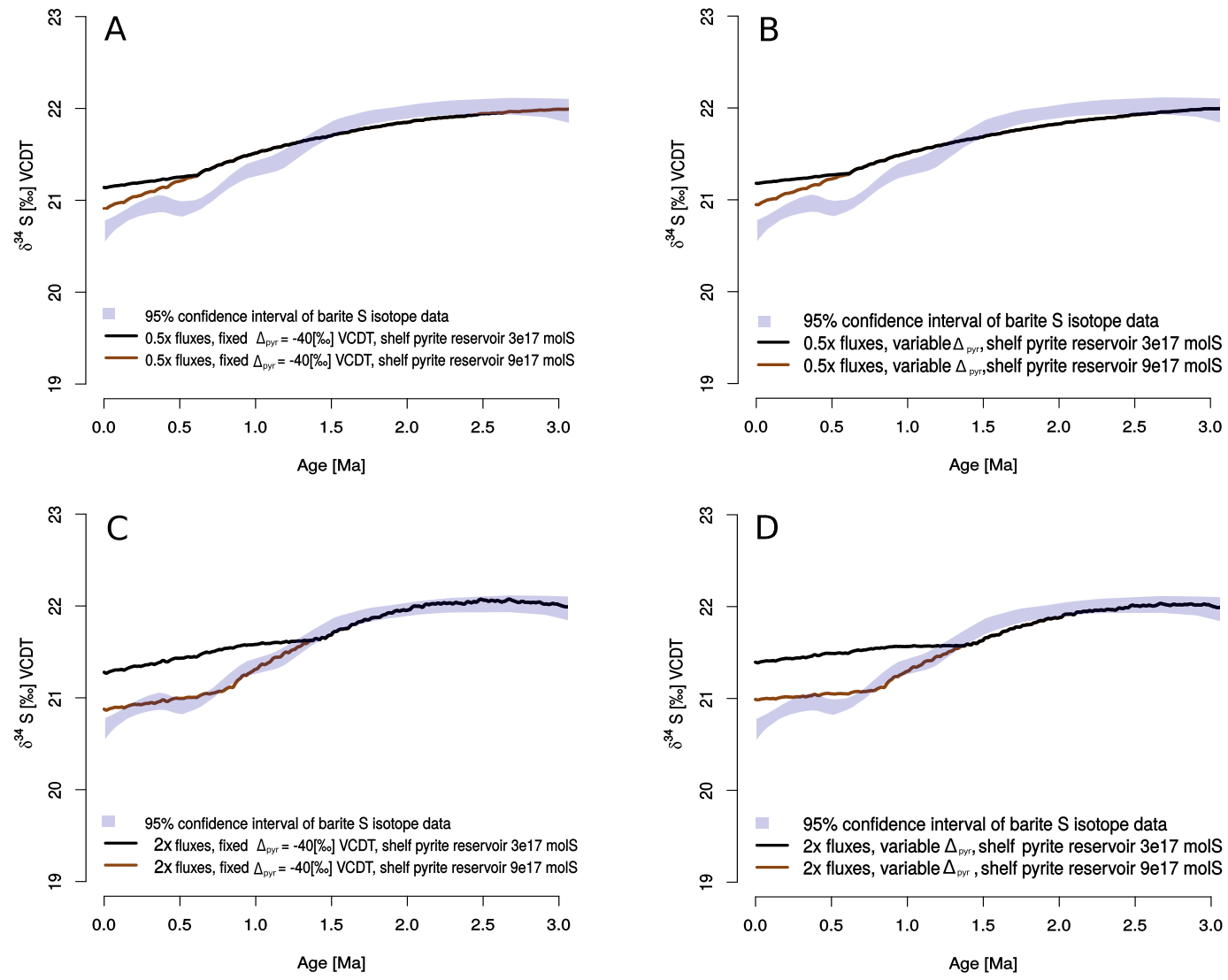

Figure A3. Sensitivity model tests. (a) Model output using fixed $\Delta_{\text {pyr }}$ and assuming initial fluxes at $50 \%$ steady state values. (b) Model output using variable $\Delta_{\text {pyr }}$ and assuming initial fluxes at $50 \%$ steady state values. (c) Model output using fixed $\Delta_{\text {pyr }}$ and assuming initial fluxes at $200 \%$ steady state values. (d) Model output using variable $\Delta_{\text {pyr }}$ and assuming initial fluxes at $200 \%$ steady state values. Note: black solid line - model outputs produced assuming the low estimate for shelf pyrite sub-reservoir. Brown solid line - model outputs produced assuming the high estimate for shelf pyrite sub-reservoir. The shaded area represents the $95 \%$ confidence interval of a LOESS approximation of the "true" $\delta^{34} \mathrm{~S}_{\mathrm{SO}_{4}}$ value (for forcing see Figs. A4-A5). 

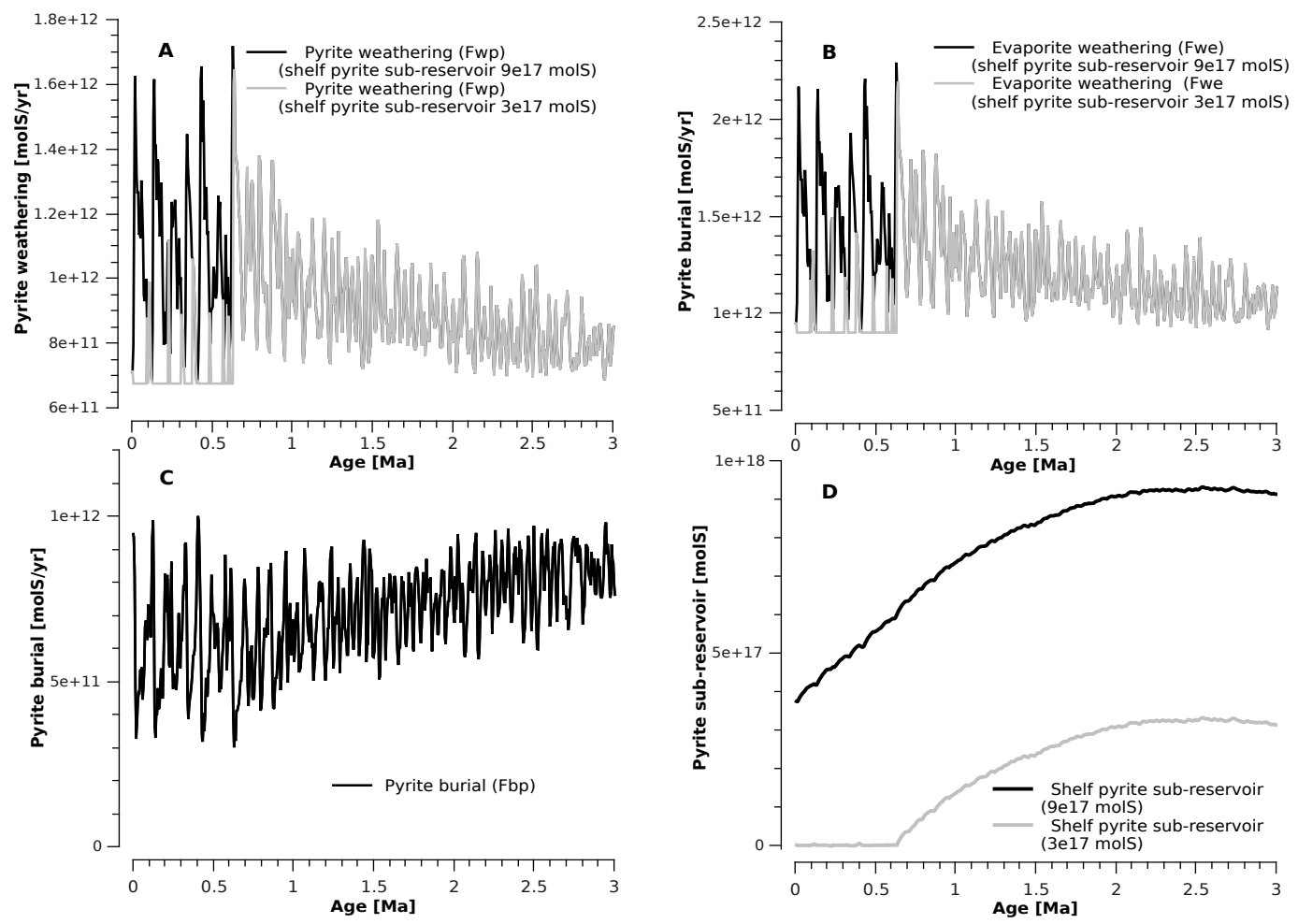

Figure A4. Model forcing with initial fluxes at $50 \%$ steady state values. (a) Pyrite weathering $\left(F_{\text {wp }}\right)$. (b) Evaporite weathering $\left(F_{\text {we }}\right)$. (c) Pyrite burial $\left(F_{\mathrm{bp}}\right)$. (d) Pyrite sub-reservoir on the shelf. Note: the pyrite burial flux is not affected by the size of initial pyrite shelf sub-reservoir.
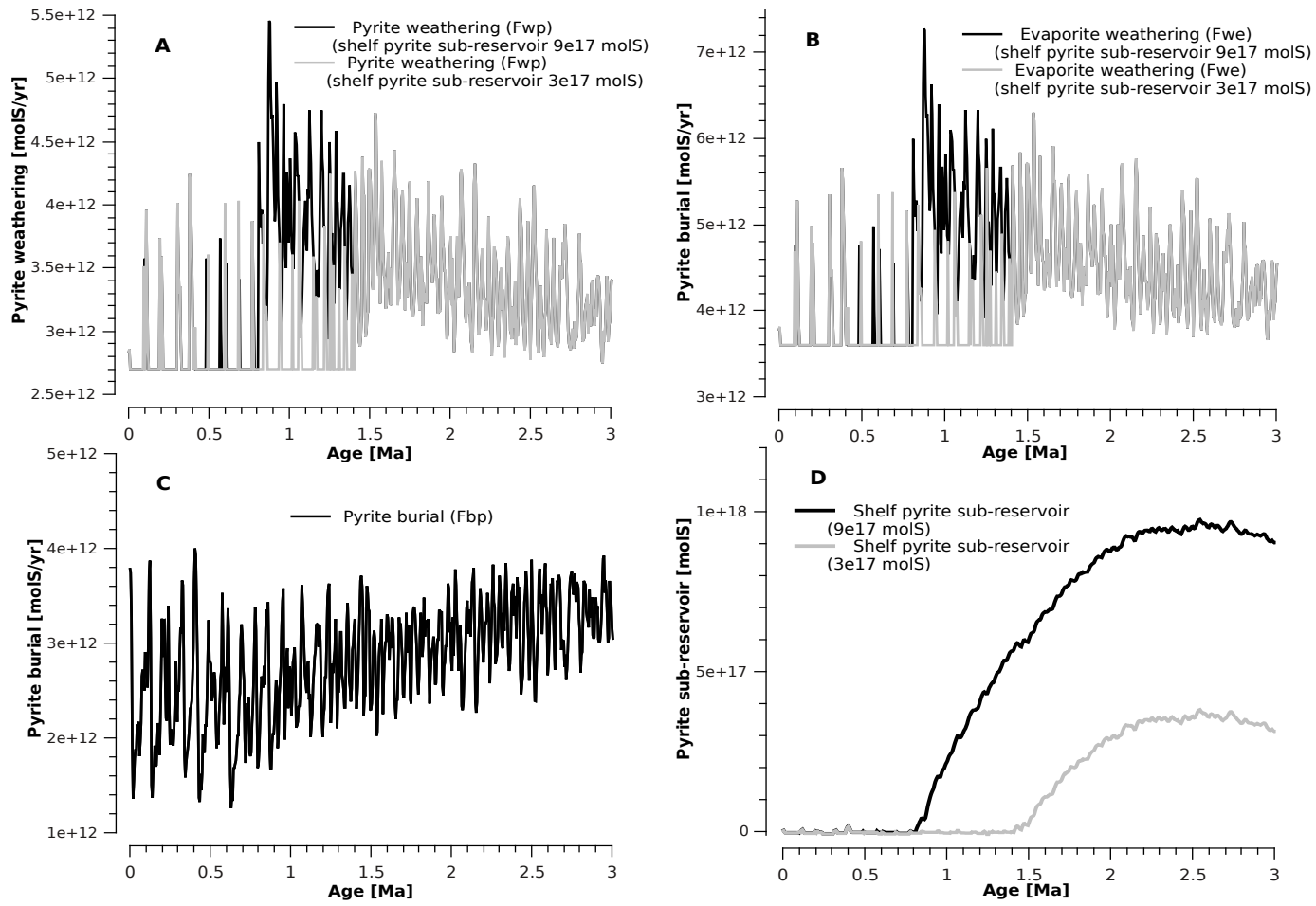

Figure A5. Model forcing with initial fluxes at $200 \%$ steady state values. (a) Pyrite weathering $\left(F_{\mathrm{wp}}\right)$. (b) Evaporite weathering $\left(F_{\mathrm{we}}\right)$. (c) Pyrite burial $\left(F_{\mathrm{bp}}\right)$. (d) Pyrite sub-reservoir on the shelf. Note: the pyrite burial flux is not affected by the size of pyrite shelf sub-reservoir. 
Author contributions. S. Markovic produced the isotopic data and developed the modeling methodology; all authors assisted in drafting of the manuscript.

Acknowledgements. We thank B. Brunner and B. Wing for discussions and comments on an early draft of this manuscript and Hong Li for help with isotope analyses. Additionally, we thank P. Meister, B. Mayer and one anonymous reviewer for constructive reviews, and T. Treude for editorial handling of the manuscript. This project was supported by a NSERC discovery grant to UGW.

Edited by: T. Treude

\section{References}

Aller, R. C., Mackin, J. E., and Cox, R. T.: Diagenesis Of Fe And S In Amazon Inner Shelf Muds - Apparent Dominance Of Fe Reduction And Implications For The Genesis Of Ironstones, Cont. Shelf Res., 6, 263-289, doi:10.1016/0278-4343(86)900646, 1986.

Berner, R. A.: Burial Of Organic-Carbon And Pyrite Sulfur In The Modern Ocean - Its Geochemical And Environmental Significance, Am. J. Sci., 282, 451-473, 1982.

Berner, R. A.: Models For Carbon And Sulfur Cycles And Atmospheric Oxygen - Application To Paleozoic Geologic History, Am. J. Sci., 287, 177-196, 1987.

Bjerrum, C. J., Bendtsen, J., and Legarth, J. J. F.: Modeling organic carbon burial during sea level rise with reference to the Cretaceous, Geochem. Geophy. Geosy., 7, 1-24, doi:10.1029/2005gc001032, 2006.

Böttcher, M. E., Thamdrup, B., and Vennemann, T. W.: Oxygen and sulfur isotope fractionation during anaerobic bacterial disproportionation of elemental sulfur, Geochim. Cosmochim. Ac., 65, 1601-1609, doi:10.1016/s0016-7037(00)00628-1, 2001.

Böttcher, M. E., Thamdrup, B., Gehre, M., and Theune, A.: S-34/S32 and $\mathrm{O}-18 / \mathrm{O}-16$ fractionation during sulfur disproportionation by Desulfobulbus propionicus, Geomicrobiol. J., 22, 219-226, doi:10.1080/01490450590947751, 2005.

Bottrell, S. H. and Newton, R. J.: Reconstruction of changes in global sulfur cycling from marine sulfate isotopes, Earth-Sci. Rev., 75, 59-83, doi:10.1016/j.earscirev.2005.10.004, 2006.

Breit, G. N., Simmons, E. C., and Goldhaber, M. B.: Dissolution Of Barite For The Analysis Of Strontium Isotopes And Other Chemical And Isotopic Variations Using Aqueous Sodium-Carbonate, Chem. Geol., 52, 333-336, doi:10.1016/0168-9622(85)90043-0, 1985.

Brennan, S. T., Lowenstein, T. K., and Cendon, D. I.: The Major-Ion Composition Of Cenozoic Seawater: The Past 36 Million Years From Fluid Inclusions In Marine Halite, Am. J. Sci., 313, 713775, doi:10.2475/08.2013.01, 2013.

Brunner, B. and Bernasconi, S. M.: A revised isotope fractionation model for dissimilatory sulfate reduction in sulfate reducing bacteria, Geochim. Cosmochim. Ac., 69, 4759-4771, doi:10.1016/j.gca.2005.04.015, 2005.

Brüchert, V., Jørgensen, B. B., Neumann, K., Riechmann, D., Schlösser, M. and Schulz, H.: Regulation of bacterial sulfate reduction and hydrogen sulfide fluxes in the central Namibian coastal upwelling zone, Geochim. Cosmochim. Ac., 67, 45054518, doi:10.1016/S0016-7037(03)00275-8, 2003.

Calmels, D., Gaillardet, J., Brenot, A., and France-Lanord, C.: Sustained sulfide oxidation by physical erosion processes in the Mackenzie River basin: Climatic perspectives, Geology, 35, 1003-1006, doi:10.1130/g24132a.1, 2007.

Canfield, D. E.: The evolution of the Earth surface sulfur reservoir, Am. J. Sci., 304, 839-861, doi:10.2475/ajs.304.10.839, 2004.

Canfield, D. E.: Sulfur isotopes in coal constrain the evolution of the Phanerozoic sulfur cycle, P. Natl. Acad. USA, 110, 8443-8446, doi:10.1073/pnas.1306450110, 2013.

Canfield, D. E. and Thamdrup, B.: The production of 34S-depleted sulfide during bacterial disproportionation of elemental sulfur, Science, 266, 1973-1975, 1994.

Canfield, D. E., Raiswell, R., and Bottrell, S.: The Reactivity Of Sedimentary Iron Minerals Toward Sulfide, Am. J. Sci., 292, 659-683, 1992.

Canheld, D. E., Boudreau, B. P., Mucci, A., and Gundersen, J. K.: The early diagenetic formation of organic sulfur in the sediments of Mangrove Lake, Bermuda, Geochim. Cosmochim. Ac., 62, 767-781, doi:10.1016/S0016-7037(98)00032-5, 1998.

Charlson, R. J., Anderson, T. L., and McDuff, R. E.: The sulfur cycle, International Geophysics Series, Global Biogeochem. Cy., 50, 285-300, 1992.

Clark, P. U., Archer, D., Pollard, D., Blum, J. D., Rial, J. A., Brovkin, V., Mix, A. C., Pisias, N. G., and Roy, M.: The middle Pleistocene transition: characteristics. mechanisms, and implications for long-term changes in atmospheric PCO2, Quaternary Sci. Rev., 25, 3150-3184, doi:10.1016/j.quascirev.2006.07.008, 2006.

Claypool, G. E., Holser, W. T., Kaplan, I. R., Sakai, H., and Zak, I.: The Age Curves Of Sulfur And Oxygen Isotopes In Marine Sulfate And Their Mutual Interpretation, Chem. Geol., 28, 199230, doi:10.1016/0009-2541(80)90047-9, 1980.

Cleveland, W. S.: Robust Locally Weighted Regression and Smoothing Scatterplots, J. Am. Stat. Assoc., 74, 829-836, 1979.

Cogné, J. P. and Humler, E.: Trends and rhythms in global seafloor generation rate, Geochem. Geophy. Geosy., 7, Q03011, doi:10.1029/2005gc001148, 2006.

Colley, S., Thomson, J., Wilson, T. R., and Higgs, N.: Postdepositional migration of elements during diagenesis in brown clay and turbidite sequences in the North East Atlantic, Geochim. Cosmochim. Ac., 48, 1223-1235, doi:10.1016/00167037(84)90057-7, 1984.

Coplen, T. B., Hopple, J. A., Böhlke, J. K., Peiser, H. S., Rieder, S. E., Krouse, H. R., Rosman, K. J. R., Ding, T., Vocke Jr., R. D., Révész, K .M., Lamberty, A., Taylor, P., and De Bièvre, P.: Compilation of minimum and maximum isotope ratios of selected elements in naturally occurring terrestrial materials and reagents, US Geological Survey Water-Resources Investigations Report 01-4222, 2001.

Cowie, G. L., Hedges, J. I., Prahl, F. G., and de Lange, G. J.: Elemental and major biochemical changes across an oxidation front in a relict turbidite: An oxygen effect, Geochim. Cosmochim. Ac., 59, 33-46, doi:10.1016/0016-7037(94)00329-K, 1995.

de Haas, H., van Weering, T. C. E., and de Stieger, H.: Organic carbon in shelf seas: sinks or sources, processes and products, Cont. 
Shelf Res., 22, 691-717, doi:10.1016/s0278-4343(01)00093-0, 2002.

De Lange, G. J.: Oxic vs. anoxic diagenetic alteration of turbidite sediments in the Madeira Abyssal Plain, eastern North Atlantic, in: Proceedings of the Ocean Drilling Program, edited by: Weaver, P. P. E., Schmincke, H.-U., Firth, J. V., and Duffileld, W., Scientific Results, 157, 573-579, 1998.

Dean, W. E., Gardner, J. V., and Piper, D. Z.: Inorganic geochemical indicators of glacial-interglacial changes in productivity and anoxia on the California continental margin, Geochim. Cosmochim. Ac., 61, 4507-4518, doi:10.1016/s00167037(97)00237-8, 1997.

DeBond, N., Oakes, R. L., Paytan, A., and Wortmann, U. G.: Early Aptian carbon and sulphur isotope signatures at ODP Site 765, Isot. Environ. Healt. S., 48, 180-194, doi:10.1080/10256016.2012.659732, 2012.

Filippelli, G. M., Latimer, J. C., Murray, R. W., and Flores, J.-A.: Productivity records from the Southern Ocean and the equatorial Pacific Ocean: Testing the glacial ShelfNutrient Hypothesis, Deep-Sea Res. Pt., 54, 2443-2452, doi:10.1016/j.dsr2.2007.07.021, 2007.

Foster, G. L. and Vance, D.: Negligible glacial-interglacial variation in continental chemical weathering rates, Nature, 444, 918-921, doi:10.1038/nature05365, 2006.

Francois, R. and Bacon, M. P.: Geochemical archives encoded in deep-sea sediments offer clues for reconstructing the ocean's role in past climatic changes, Oceanus, 40, 29-32, 1997.

Ganeshram, R. S., Pedersen, T. F., Calvert, S. E., and Francois, R.: Reduced nitrogen fixation in the glacial ocean inferred from changes in marine nitrogen and phosphorus inventories, Nature, 415, 156-159, doi:10.1038/415156a, 2002.

Garrels, R. M. and Lerman, A.: Phanerozoic Cycles Of Sedimentary Carbon And Sulfur, P. Natl. Acad. Sci. USA, 78, 4652-4656, doi:10.1073/pnas.78.8.4652, 1981.

Gibbs, M. T. and Kump, L. R.: Global Chemical Erosion During The Last Glacial Maximum And The Present - Sensitivity To Changes In Lithology And Hydrology, Paleoceanography, 9, 529-543, doi:10.1029/94pa01009, 1994.

Goldhaber, M.: Sulfur-rich sediments, Treatise on Geochemistry, 7, 254-288, doi:10.1016/B0-08-043751-6/07139-5, 2003.

Goldhaber, M. B. and Kaplan, I. R.: Controls And Consequences Of Sulfate Reduction Rates In Recent Marine Sediments, Soil Sci., 119, 42-55, doi:10.1097/00010694-197501000-00008, 1975.

Griffith, E. M. and Paytan, A.: Barite in the ocean - occurrence, geochemistry and palaeoceanographic applications, Sedimentology, 59, 1817-1835, doi:10.1111/j.1365-3091.2012.01327.x, 2012.

Halevy, I., Peters, S. E., and Fischer, W. W.: Sulfate Burial Constraints on the Phanerozoic Sulfur Cycle, Science, 337, 331-334, doi:10.1126/science.1220224, 2012.

Hansen, K. W. and Wallmann, K.: Cretaceous and cenozoic evolution of seawater composition, atmospheric $\mathrm{O}-2$ and $\mathrm{CO}_{2}$ : $\mathrm{A}$ model perspective, Am. J. Sci., 303, 94-148, 2003.

Hay, W. W.: Detrital sediment fluxes from continents to oceans, Chem. Geol., 145, 287-323, doi:10.1016/s0009-2541(97)001496, 1998.

Hay, W. W. and Southam, J. R.: Modulation of sedimentation by the continental shelves, in: The fate of fossil fuel $\mathrm{C}_{2}$ in the oceans, Plenum Press, New York, 569-604, 1977.
Hay, W. W., Soeding, E., DeConto, R. M., and Wold, C. N.: The Late Cenozoic uplift - climate change paradox, Int. J. Earth Sci., 91, 746-774, doi:10.1007/s00531-002-0263-1, 2002.

Hedges, J. I. and Keil, R. G.: Sedimentary organic matter preservation: an assessment and speculative synthesis, Mar. Chem., 49, 137-139, doi:10.1016/0304-4203(95)00013-H, 1995.

Hoenisch, B., Hemming, N. G., Archer, D., Siddall, M., and McManus, J. F.: Atmospheric Carbon Dioxide Concentration Across the Mid-Pleistocene Transition, Science, 324, 15511554, doi:10.1126/science.1171477, 2009.

Horita, J., Zimmermann, H., and Holland, H. D.: Chemical evolution of seawater during the Phanerozoic: Implications from the record of marine evaporites, Geochim. Cosmochim. Ac., 66, 3733-3756, doi:10.1016/s0016-7037(01)00884-5, 2002.

$\mathrm{Hu}, \mathrm{X}$. and Cai, W. J.: An assessment of ocean margin anaerobic processes on oceanic alkalinity budget, Global Biogeochem. Cy., 25, GB3003, doi:10.1029/2010GB003859, 2011.

Jaccard, S. L., Galbraith, E. D., Sigman, D. M., and Haug, G. H.: A pervasive link between Antarctic ice core and subarctic Pacific sediment records over the past 800 kyrs, Quaternary Sci. Rev., 29, 206-212, doi:10.1016/j.quascirev.2009.10.007, 2010.

Johnston, D. T., Farquhar, J., Habicht, K. S., and Canfield, D. E.: Sulphur isotopes and the search for life: strategies for identifying sulphur metabolisms in the rock record and beyond, Geobiology, 6, 425-435, doi:10.1111/j.1472-4669.2008.00171.x, 2008.

Jørgensen, B. B.: Mineralization Of Organic-Matter In The Sea Bed - The Role Of Sulfate Reduction, Nature, 296, 643-645, doi:10.1038/296643a0, 1982.

Jørgensen, B. B. and Kasten, S.: Marine Geochemistry, chap. Sulfur cycling and methane oxidation, Springer, Berlin, 2nd Edn., 271309, 2006.

Kaiho, K. and Saito, S.: Oceanic-Crust Production And Climate During The Last 100-Myr, Terra Nova, 6, 376-384, doi:10.1111/j.1365-3121.1994.tb00510.x, 1994.

Kampschulte, A. and Strauss, H.: The sulfur isotopic evolution of Phanerozoic seawater based on the analysis of structurally substituted sulfate in carbonates, Chem. Geol., 204, 255-286, doi:10.1016/j.chemgeo.2003.11.013, 2004.

Keeling, R. F., Kortzinger, A., and Gruber, N.: Ocean Deoxygenation in a Warming World, in: Annual Review of Marine Science, Annual Review of Marine Science, Annual Reviews, Palo Alto, 199-229, 2010.

Kump, L. R.: Alternative Modeling Approaches To The Geochemical Cycles Of Carbon, Sulfur, And Strontium Isotopes, Am. J. Sci., 289, 390-410, 1989.

Kurtz, A., Kump, L. R., Arthur, M. A., Zachos, J. C.,and Paytan, A.: Early Cenozoic decoupling of the global carbon and sulfur cycles, Paleoceanography, 18, 1090, doi:10.1029/2003PA000908, 2003.

Leavitt, W. D., Halevy, I., Bradley, A. S., and Johnston, D. T.: Influence of sulfate reduction rates on the Phanerozoic sulfur isotope record, P. Natl. Acad. USA, 110, 11244-11249, doi:10.1073/pnas.1218874110, 2013.

Lisiecki, L. E. and Raymo, M. E.: A Pliocene-Pleistocene stack of 57 globally distributed benthic delta O-18 records, Paleoceanography, 20, PA1003, doi:10.1029/2004pa001071, 2005.

Mangini, A., Jung, M., and Laukenmann, S.: What do we learn from peaks of uranium and of manganese in deep sea sediments?, Mar. Geol., 177, 63-78, doi:10.1016/s0025-3227(01)00124-4, 2001. 
Mason, B. G., Pyle, D. M., and Oppenheimer, C.: The size and frequency of the largest explosive eruptions on Earth, B. Volcanol., 66, 735-748, doi:10.1007/s00445-004-0355-9, 2004.

Meiburg, E. and Kneller, B.: Turbidity Currents and Their Deposits, Annu. Rev. Fluid Mech., 42, 135-156, doi:10.1146/annurevfluid-121108-145618, 2010.

Miller, K. G., Mountain, G. S., Wright, J. D., and Browning, J. V.: A 180-Million-Year Record of Sea Level and Ice Volume Variations from Continental Margin and Deep-Sea Isotopic Records, Oceanography, 24, 40-53, 2011.

Morse, J. W. and Emeis, K. C.: Controls on $\mathrm{C} / \mathrm{S}$ ratios in hemipelagic upwelling sediments, Am. J. Sci., 290, 1117-1135, doi:10.2475/ajs.290.10.1117, 1990.

Mossmann, J.-R., Aplin, A. C., Curtis, C. D., and Coleman, M. L.: Geochemistry of inorganic and organic sulphur in organic-rich sediments from the Peru Margin, Geochim. Cosmochim. Ac., 55, 3581-3595, doi:10.1016/0016-7037(91)90057-C, 1991.

Murray, R. W., Leinen, M., and Isern, A. R.: Biogenic Flux Of A1 To Sediment In The Central Equatorial Pacific-Ocean - Evidence For Increased Productivity During Glacial Periods, Paleoceanography, 8, 651-670, doi:10.1029/93pa02195, 1993.

Nameroff, T. J., Calvert, S. E., and Murray, J. W.: Glacialinterglacial variability in the eastern tropical North Pacific oxygen minimum zone recorded by redox-sensitive trace metals, $\mathrm{Pa}-$ leoceanography, 19, PA1010, doi:10.1029/2003pa000912, 2004.

National Geophysical Data Center: ETOPO-5 bathymetry/topography data, Data Announcement 88-MGG-02, Natl.Oceanic and Atmos. Admin., US Dep. of Comm., Boulder, Colorado, 1988.

Paytan, A., Kastner, M., and Chavez, F. P.: Glacial to interglacial fluctuations in productivity in the equatorial $\mathrm{Pa}-$ cific as indicated by marine barite, Science, 274, 1355-1357, doi:10.1126/science.274.5291.1355, 1996.

Paytan, A., Kastner, M., Campbell, D., and Thiemens, M. H.: Sulfur isotopic composition of Cenozoic seawater sulfate, Science, 282, 1459-1462, doi:10.1126/science.282.5393.1459, 1998.

Paytan, A., Mearon, S., Cobb, K. M., and Kastner, M.: Origin of marine barite deposits: $\mathrm{Sr}$ and $\mathrm{S}$ isotope characterization, Geology, 30, 747-750, doi:10.1130/00917613(2002)030<0747:oombds>2.0.co;2, 2002.

Paytan, A., Kastner, M., Campbell, D., and Thiemens, M. H.: Seawater sulfur isotope fluctuations in the Cretaceous, Science, 304, 1663-1665, 2004.

Petsch, S. T. and Berner, R. A.: Coupling the geochemical cycles of $\mathrm{C}, \mathrm{P}, \mathrm{Fe}$, and $\mathrm{S}$ : The effect on atmospheric O-2 and the isotopic records of carbon and sulfur, Am. J. Sci., 298, 246-262, 1998.

Piper, D. J. W. and Normark, W. R.: Processes That Initiate Turbidity Currents and Their Influence on Turbidites: A Marine Geology Perspective, J. Sediment. Res., 79, 347-362, doi:10.2110/jsr.2009.046, 2009.

Poulton, S. W. and Raiswell, R.: The low-temperature geochemical cycle of iron: From continental fluxes to marine sediment deposition, Am. J. Sci., 302, 774-805, doi:10.2475/ajs.302.9.774, 2002.

R Core Team, R: A language and environment for statistical computing, R Foundation for Statistical Computing, Vienna, Austria, 2012

Raiswell, R. and Canfield, D. E.: Sources of iron for pyrite formation in marine sediments, Am. J. Sci., 298, 219-245, 1998.
Raiswell, R., Tranter, M., Benning, L. G., Siegert, M., De'ath, R., Huybrechts, P., and Payne, T.: Contributions from glacially derived sediment to the global iron (oxyhydr)oxide cycle: Implications for iron delivery to the oceans, Geochim. Cosmochim. Ac., 70, 2765-2780, doi:10.1016/j.gca.2005.12.027, 2006.

Raymo, M. E., Ruddiman, W. F., and Froelich, P. N.: Influence Of Late Cenozoic Mountain Building On Ocean Geochemical Cycles, Geology, 16, 649-653, 10.1130/00917613(1988)016<0649:iolcmb>2.3.co;2, 1988.

Robinson, S. G.: Early diagenesis in an organic-rich turbidite and pelagic clay sequence from the Cape Verde Abyssal Plain, NE Atlantic: Magnetic and geochemical signals, Sediment. Geol., 143, 91-123, doi:10.1016/S0037-0738(00)00187-1, 2001.

Rudnicki, M. D., Elderfield, H., and Spiro, B.: Fractionation of sulfur isotopes during bacterial sulfate reduction in deep ocean sediments at elevated temperatures, Geochim. Cosmochim. Ac., 65, 777-789, doi:10.1016/s0016-7037(00)00579-2, 2001.

Ruttenberg, K. C.: The Global Phosphorus Cycle, in: Treatise on Geochemistry, 8, Elsevier, Amsterdam, 585-643, 2003.

Schroth, A. W., Crusius, J., Hoyer, I., and Campbell, R.: Estuarine removal of glacial iron and implications for iron fluxes to the ocean, Geophys. Res. Lett., 41, 3951-3958, doi:10.1002/2014g1060199, 2014.

Seal II, R. R.: Sulfur isotope geochemistry of sulfide minerals, Rev. Mineral. Geochem., 61, 633-677, doi:10.2138/rmg.2006.61.12, 2006.

Sim, M. S., Bosak, T., and Ono, S.: Large Sulfur Isotope Fractionation Does Not Require Disproportionation, Science, 333, 74-77, doi:10.1126/science.1205103, 2011.

Shackleton, N. J., Crowhurst, S., Hagelberg, T., Pisias, N. G., and Schneider, D. A.: A new late Neogene time scale: application to Leg 138 sites, in: Proceedings of the Ocean Drilling Program, Scientific results, edited by: Pisias, N. G., Mayer, L.A., Janecek, T. R., Palmer-Julson, A., and van Andel, T. H., ODP, Ocean Drilling program, College Station, TX, 138, 73-101, doi:10.2973/odp.proc.sr.138.106.1995, 1995.

Schenau, S. J., Passier, H. F., Reichart, G. J., and De Lange, G. J.: Sedimentary pyrite formation in the Arabian Sea, Mar. Geol., 185, 393-402, doi:10.1016/S0025-3227(02)00183-4, 2002.

Shipboard Scientific Party: Site 849, Proceedings of the Ocean Drilling Program, in: Proceedings of the Ocean Drilling Program, Initial Reports, edited by: Mayer, L., Pisias, N., Janecek, T. R., Palmer-Julson, A., and van Andel, T. H., ODP, Ocean Drilling program, College Station, TX, 138, 735-807, doi:10.2973/odp.proc.ir.138.114.1992, 1992a.

Shipboard Scientific Party: Site 851, Proceedings of the Ocean Drilling Program, in: Proceedings of the Ocean Drilling Program, Initial Reports, edited by: Mayer, L., Pisias, N., Janecek, T. R., Palmer-Julson, A., and van Andel, T. H., ODP, Ocean Drilling program, College Station, TX, 138, 891-965, doi:10.2973/odp.proc.ir.138.116.1992, 1992b.

Spence, J. and Telmer, K.: The role of sulfur in chemical weathering and atmospheric $\mathrm{CO}_{2}$ fluxes: Evidence from major ions, delta C-13(DIC), and delta S-34(SO4) in rivers of the Canadian Cordillera, Geochim. Cosmochim. Ac., 69, 5441-5458, doi:10.1016/j.gca.2005.07.011, 2005.

Strauss, H.: The isotopic composition of sedimentary sulfur through time, Palaeogeogr. Palaeoecl., 132, 97-118, doi:10.1016/s00310182(97)00067-9, 1997. 
Suits, N. S. and Arthur, M. A.: Sulfur diagenesis and partitioning in Holocene Peru shelf and upper slope sediments, Chem. Geol., 163, 219-234, doi:10.1016/S0009-2541(99)00114-X, 2000.

Thomson, J., Wallace, H. E., Colley, S., and Toole, J.: Authigenic Uranium In Atlantic Sediments Of The Last Glacial Stage - A Diagenetic Phenomenon, Earth Planet. Sc. Lett., 98, 222-232, doi:10.1016/0012-821x(90)90061-2, 1990.

Thomson, J., Jarvis, I., Green, D. R. H., and Green, D. J.: Oxidation fronts in Madeira abyssal plain turbidites: Persistance of early diagenetic trace-element enrichments during burial, SITE 950, in Proceedings of the Ocean Drilling Program, Scientific Results, 157, 559-571, 1998.

Thullner, M., Dale, A. W., and Regnier, P.: Global-scale quantification of mineralization pathways in marine sediments: A reactiontransport modeling approach, Geochem. Geophy. Geosy., 10, Q10012, doi:10.1029/2009gc002484, 2009.

Torres, M. A., West, A. J., and Li, G.: Sulphide oxidation and carbonate dissolution as a source of $\mathrm{CO}_{2}$ over geological timescales, Nature, 507, 346-349, doi:10.1038/nature13030, 2014.

Torres, M. E., Brumsack, H. J., Bohrmann, G., and Emeis, K. C.: Barite fronts in continental margin sediments: A new look at barium remobilization in the zone of sulfate reduction and formation of heavy barites in diagenetic fronts, Chem. Geol., 127, 125-139, doi:10.1016/0009-2541(95)00090-9, 1996.

Tostevin, R., Turchyn, A. V., Farquhar, J., Johnston, D. T., Eldridge, D. L., Bishop, J. K. B., and McIlvin, M.: Multiple sulfur isotope constraints on the modern sulfur cycle, Earth Planet. Sc. Lett., 396, 14-21, doi:10.1016/j.eps1.2014.03.057, 2014.

Turchyn, A. V. and Schrag, D. P.: Oxygen isotope constraints on the sulfur cycle over the past 10 million years, Science, 303, 20042007, 2004.

Warren, J. K.: Evaporites; sediments, resources, and hydrocarbons, Springer, Berlin, Heidelberg, New York, 2006.
Warren, J. K.: Evaporites through time: Tectonic, climatic and eustatic controls in marine and nonmarine deposits, Earth-Sci. Rev., 98, 217-268, doi:10.1016/j.earscirev.2009.11.004, 2010.

Weaver, P. P. E., Wynn, R. B., Kenyon, N. H., and Evans, J.: Continental margin sedimentation, with special reference to the north-east Atlantic margin, Sedimentology, 47, 239-256, doi:10.1046/j.1365-3091.2000.0470s1239.x, 2000.

Werne, J. P., Hollander, D. J., Lyons, T. W., and Sinninghe Damsté, J. S.: Organic sulfur biogeochemistry: Recent advances and future research directions, Geol. Soc. Am. Spec. Pap., 379, 135150, doi:10.1130/0-8137-2379-5.135, 2004.

White, S. M., Crisp, J. A., and Spera, F. J.: Long-term volumetric eruption rates and magma budgets, Geochem. Geophy. Geosy., 7, Q03010, doi:10.1029/2005gc001002, 2006.

Wollast, R.: The Coastal Organic-Carbon Cycle - Fluxes, Sources, And Sinks, Ocean Margin Processes in Global Change, 365-381, J. Wiley \& Sons, Chichester, 1991.

Wortmann, U. G., Bernasconi, S. M., and Bottcher, M. E.: Hypersulfidic deep biosphere indicates extreme sulfur isotope fractionation during single-step microbial sulfate reduction, Geology, 29, 647-650, doi:10.1130/00917613(2001)029<0647:hdbies>2.0.co;2, 2001.

Wortmann, U. G. and Chernyavsky, B. M.: Effect of evaporite deposition on Early Cretaceous carbon and sulphur cycling, Nature, 446, 654-656, doi:10.1038/nature05693, 2007.

Wortmann, U. G. and Paytan, A.: Rapid Variability of Seawater Chemistry Over the Past 130 Million Years, Science, 337, 334 336, doi:10.1126/science.1220656, 2012.

Zimmermann, H.: Tertiary seawater chemistry - Implications from primary fluid inclusions in marine halite, Am. J. Sci., 300, 723767, doi:10.2475/ajs.300.10.723, 2000. 